\title{
Cross-polar transport and scavenging of Siberian aerosols containing black carbon during the 2012 ACCESS summer campaign
}

\author{
Jean-Christophe Raut ${ }^{1}$, Louis Marelle ${ }^{1, a}$, Jerome D. Fast ${ }^{2}$, Jennie L. Thomas ${ }^{1}$, Bernadett Weinzierl ${ }^{3,4,5}$, \\ Katharine S. Law ${ }^{1}$, Larry K. Berg ${ }^{2}$, Anke Roiger ${ }^{3}$, Richard C. Easter ${ }^{2}$, Katharina Heimer ${ }^{3,4,5}$, Tatsuo Onishi ${ }^{1}$, \\ Julien Delanoë ${ }^{1}$, and Hans Schlager ${ }^{3}$ \\ ${ }^{1}$ LATMOS/IPSL, UPMC Univ. Paris 06 Sorbonne Universités, UVSQ, CNRS, Paris, France \\ ${ }^{2}$ Pacific Northwest National Laboratory, Richland, WA, USA \\ ${ }^{3}$ Deutsches Zentrum für Luft- und Raumfahrt (DLR), Institut für Physik der Atmosphäre, Oberpfaffenhofen, Germany \\ ${ }^{4}$ Ludwig-Maximilians-Universität, Meteorologisches Institut, Munich, Germany \\ ${ }^{5}$ University of Vienna, Aerosol Physics and Environmental Physics, Vienna, Austria \\ ${ }^{a}$ now at: Center for International Climate and Environmental Research, Oslo, Norway
}

Correspondence to: Jean-Christophe Raut (jean-christophe.raut@latmos.ipsl.fr)

Received: 18 November 2016 - Discussion started: 13 January 2017

Revised: 5 May 2017 - Accepted: 7 August 2017 - Published: 15 September 2017

\begin{abstract}
During the ACCESS airborne campaign in July 2012, extensive boreal forest fires resulted in significant aerosol transport to the Arctic. A 10-day episode combining intense biomass burning over Siberia and low-pressure systems over the Arctic Ocean resulted in efficient transport of plumes containing black carbon (BC) towards the Arctic, mostly in the upper troposphere $(6-8 \mathrm{~km})$. A combination of in situ observations (DLR Falcon aircraft), satellite analysis and WRF-Chem simulations is used to understand the vertical and horizontal transport mechanisms of $\mathrm{BC}$ with a focus on the role of wet removal. Between the northwestern Norwegian coast and the Svalbard archipelago, the Falcon aircraft sampled plumes with enhanced $\mathrm{CO}$ concentrations up to $200 \mathrm{ppbv}$ and $\mathrm{BC}$ mixing ratios up to $25 \mathrm{ng} \mathrm{kg}^{-1}$. During transport to the Arctic region, a large fraction of $\mathrm{BC}$ particles are scavenged by two wet deposition processes, namely wet removal by large-scale precipitation and removal in wet convective updrafts, with both processes contributing almost equally to the total accumulated deposition of BC. Our results underline that applying a finer horizontal resolution (40 instead of $100 \mathrm{~km}$ ) improves the model performance, as it significantly reduces the overestimation of $\mathrm{BC}$ levels observed at a coarser resolution in the mid-troposphere. According to the simulations at $40 \mathrm{~km}$, the transport efficiency of $\mathrm{BC}\left(\mathrm{TE}_{\mathrm{BC}}\right)$ in biomass burning plumes was larger $(60 \%)$, because it was impacted by small accumulated precipita-
\end{abstract}

tion along trajectory $(1 \mathrm{~mm})$. In contrast $\mathrm{TE}_{\mathrm{BC}}$ was small $(<30 \%)$ and accumulated precipitation amounts were larger $(5-10 \mathrm{~mm})$ in plumes influenced by urban anthropogenic sources and flaring activities in northern Russia, resulting in transport to lower altitudes. $\mathrm{TE}_{\mathrm{BC}}$ due to large-scale precipitation is responsible for a sharp meridional gradient in the distribution of $\mathrm{BC}$ concentrations. Wet removal in cumulus clouds is the cause of modeled vertical gradient of $\mathrm{TE}_{\mathrm{BC}}$, especially in the mid-latitudes, reflecting the distribution of convective precipitation, but is dominated in the Arctic region by the large-scale wet removal associated with the formation of stratocumulus clouds in the planetary boundary layer (PBL) that produce frequent drizzle.

\section{Introduction}

The Arctic region is particularly sensitive to environmental change, as it is predicted to warm faster than any other region (Manabe et al., 1992). In the past decades, a significant loss of the summertime sea-ice extent has been detected (e.g., Lindsay et al., 2009). A substantial increase in oil and gas extraction activities as well as in shipping may result from a warmer Arctic (Corbett et al., 2010; IPCC, 2013). Recently, studies have highlighted the role of shorter- 
lived climate forcers (SLCFs), e.g., aerosols and ozone in this warming (Tomasi et al., 2007; Law and Stohl, 2007; Quinn et al., 2008; AMAP, 2015), perturbing the polar radiative balance directly by absorbing and scattering radiation (Shindell and Faluvegi, 2009), and indirectly due to aerosol effects on clouds properties leading to increases in shortwave scattering efficiency and IR emissivity of Arctic clouds (Garrett and Zhao, 2006; Lubin and Vogelmann, 2006; Zhao and Garrett, 2015). Black carbon (BC) is only a minor contributor to aerosol mass but is clearly a significant SLCF in the atmosphere and can be deposited onto snow and ice surfaces, reducing their albedo due to multiple scattering in the snowpack and the much larger absorption coefficient of BC than ice (Warren and Wiscombe, 1980; Hansen and Nazarenko, 2004; Jacobson, 2004), modifying snow grain size and facilitating snow melt, which drives changes in surface temperature (Flanner et al., 2007, 2009; Jacobson, 2010).

Winter and spring have been the most favored seasons for Arctic aerosol research, while fewer summertime measurement studies have been carried out when aerosol mixing ratios are generally smaller (Law and Stohl, 2007). More attention has been given to surface measurements, whereas only very few airborne campaigns (e.g., POLARCAT, ARCTAS) of aerosol chemical composition have been performed in summer (Schmale et al., 2011). During summer, inefficient long-range transport reveals that summertime aerosol originates from the marginal Arctic (sea-ice boundary and boreal forest regions; Warneke et al., 2010) and from episodic and rapid transport events from heavily areas, and leading to dense haze layers aloft (Browse et al., 2012; Di Pierro et al., 2013; Ancellet et al., 2014; Law et al., 2014). Some studies (Brock et al., 1989; Stohl, 2006; Paris et al., 2009) have identified boreal and temperate forest fires, especially Siberian fires, as a dominant source of BC at this season, especially above the planetary boundary layer (PBL) at altitudes between 3 and $10 \mathrm{~km}$, and even into the lower stratosphere by injection in pyrocumulus clouds (Lavoué et al., 2000). Air masses can also be uplifted to the polar tropopause during transport in warm conveyor belts (WCBs) of synoptic low-pressure systems. Eckhardt et al. (2004) and Madonna et al. (2014) have highlighted frequent WCBs over northeastern China and Russia based on climatological analyses. During the IPY (International Polar Year) in 2008, different Lagrangian studies (e.g., Roiger et al., 2011; Sodemann et al., 2011; Matsui et al., 2011) identified several Asian pollution plumes transported to the Arctic after a strong uplift in WCBs located over the Russian east coast and subsequently transported to the Arctic. Franklin et al. (2014) and Taylor et al. (2014) have documented the impact of wet removal in Canadian biomass burning plumes and confirmed that wet deposition is the dominant mechanism for BC removal from the atmosphere and consequently determining its lifetime and atmospheric burden and affecting vertical profiles of number and mass concentration.
State-of-the-art global chemical transport models have large discrepancies in modeling Arctic BC mixing ratios and seasonal variability (Shindell et al., 2008; Koch et al., 2009; Lee et al., 2013; Schwarz et al., 2013; AMAP, 2015; Schwarz et al., 2017). Vignati et al. (2010), Bourgeois and Bey (2011) and Browse et al. (2012) identified the representation of wet removal of $\mathrm{BC}$ as one of the main reasons of these differences. More recently, Breider et al. (2014) compared GEOSChem modeled BC with observations from the ARCTAS summer campaign. The mean vertical profile of BC measurements in July was always lower than $25 \mathrm{ng} \mathrm{m}^{-3}$, but the model strongly overestimated the concentrations at high altitudes influenced by long-range transport of deep convective outflow from Asian pollution (summer monsoon) and Siberian fire plumes. This result agrees with the overestimation of $\mathrm{BC}$ concentrations in the upper Arctic troposphere found by Koch and Hansen (2005). Despite an enhanced scavenging efficiency of $\mathrm{BC}$ in deep convection, Wang et al. (2014) noticed a strong overestimation of BC in the midtroposphere. Sharma et al. (2013) explained this overprediction of $\mathrm{BC}$ by an incorrect production of convective precipitation in summer in the Arctic. These results reinforce the fact that aerosol and cloud physical and chemical processing (removal, oxidation and microphysics) is the primary source of uncertainty in modeling aerosol distributions in the Arctic (Eckhardt et al., 2015).

During the summer of 2012, extensive boreal forest fires occurred both in western and in eastern Siberia (in the Yakutsk region). These fires were associated with a hottest summer on record over Siberia, leading to elevated emissions of trace gases and particles (Ponomarev, 2013). In this paper, we focus on a case of pollutant transport from Asia and Russia across the Arctic because they may ultimately lead to the transport of pollution to Europe and North America. During the ACCESS (Arctic Climate Change, Economy and Society) campaign over northern Norway in July 2012, the DLR Falcon 20 aircraft sampled plumes representative of crosspolar transport reaching the Norwegian coasts. Combining an analysis of aircraft measurements, satellite observations, Lagrangian trajectories and simulations from a regional online chemistry transport model (CTM), we investigate the horizontal spatial and vertical structure of BC-containing air masses. We focus on the factors affecting this transport, including the meteorological situation, the dry and wet deposition processes and we assess the relative contribution of anthropogenic, flaring and biomass burning sources to the BC concentrations. Section 2 describes the ACCESS campaign, as well as the modeling tools used in this study. Model output is validated against ACCESS observations in terms of meteorological and chemistry variables, aerosol optical depth (AOD), precipitation and cloud structures (Sect. 3). The export processes, the identification of plumes and the transport pathways are described in Sect. 4. Finally, Sect. 5 investigates the contribution of the various pathway-dependent aerosols 
removal processes and the transport efficiency of BC reaching the Norwegian coasts.

\section{Methodology}

\subsection{ACCESS campaign}

Roiger et al. (2015) have recently given a detailed overview of the ACCESS aircraft campaign. Therefore we only describe it briefly here. This campaign was based out of Andenes, Norway $\left(69.3^{\circ} \mathrm{N}, 16.1^{\circ} \mathrm{E}\right)$, in July 2012 and included 14 flights over the northwestern coast of Norway using the DLR Falcon 20 aircraft (Fig. 1). Most of the flights were devoted to studying the impacts of local pollution sources (ships, oil and gas extraction) on Arctic atmospheric composition (Marelle et al., 2016), but pollution from remote sources was also measured during some specific flights in the middle and upper troposphere (Roiger et al., 2015). In this study, we focus on all flights but describe in particular the two flights that both occurred on 17 July (namely flights $17 \mathrm{a}$ and $17 \mathrm{~b}$ ), which were specifically dedicated to probe father into the Arctic in order to study plumes transported from boreal and Asian sources (Fig. 1). Infrared Atmospheric Sounding Interferometer (IASI)-retrieved CO total columns as well as global trace gas forecasts from the Monitoring Atmospheric Composition and Climate (MACC) were used during the campaign to target such flights in order to identify polluted air masses in the mid- and upper troposphere (Roiger et al., 2015). In addition to the suite of meteorological instruments, the Falcon 20 was equipped with trace gas $\left(\mathrm{NO}_{x}, \mathrm{SO}_{2}, \mathrm{O}_{3}\right.$, and $\left.\mathrm{CO}\right)$ and aerosol instrumentation including $\mathrm{BC}$. $\mathrm{CO}$ was measured every second from VUV fluorescence with an accuracy of $10 \%$.

BC mass mixing ratios were measured using a singleparticle soot photometer (SP2, Droplet Measurement Technologies, Boulder, CO, USA) based on laser-induced incandescence. The instrument measures the refractory black carbon ( $\mathrm{rBC}$; hereafter referred to as $\mathrm{BC}$ ) on a single-particle basis (Schwarz et al., 2006). Particles are drawn through a highintensity $1064 \mathrm{~nm} \mathrm{Nd:YAG} \mathrm{laser} \mathrm{which} \mathrm{heats} \mathrm{BC-containing}$ particles to incandescence. Schwarz et al. (2017) detailed how the instrument had been calibrated and how the measurements had been corrected for the ACCESS campaign. The instrument has been calibrated using the recommended calibration material (fullerene soot). The individual particle masses of the $\mathrm{BC}$ cores of $\mathrm{BC}$-containing particles were averaged over $10 \mathrm{~s}$ intervals to obtain mass mixing ratios of BC. Since the SP2 instrument detected BC cores only in the size range of $80-470 \mathrm{~nm}$, assuming a density of $1.8 \mathrm{~g} \mathrm{~cm}^{-3}$ (Moteki et al., 2010), the derived mass mixing ratios were scaled by a factor to account for particles outside the detection range (as in, for example, Schwarz et al., 2006) to obtain the total mass mixing ratio. The factor was derived from the average mass size distribution of BC cores separately for

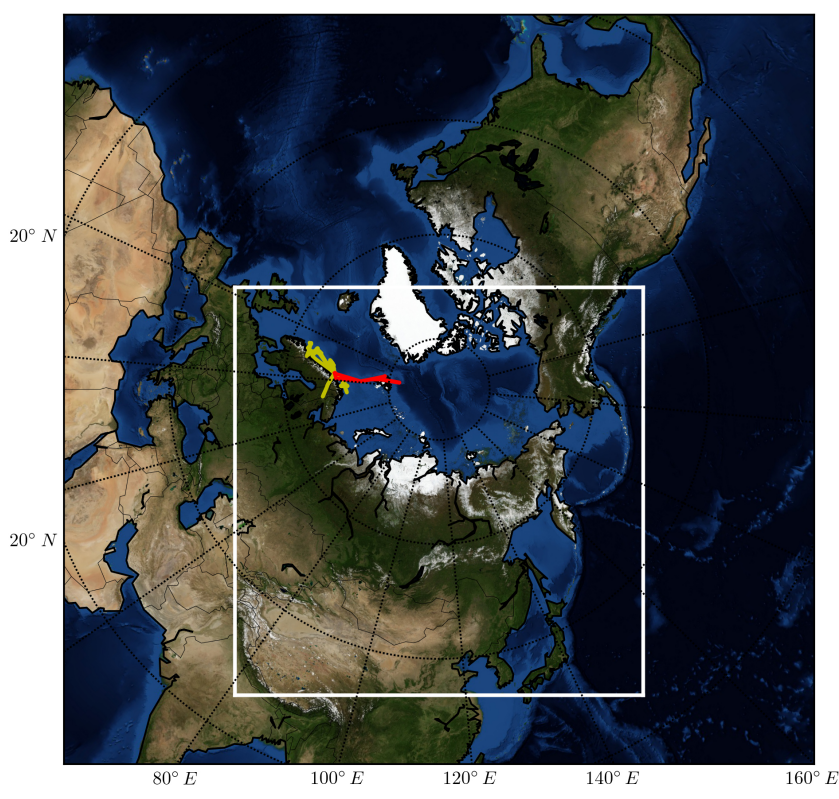

Figure 1. Map of the WRF-Chem domain (white) and the flights conducted as part of ACCESS used to evaluate the model. The Falcon 20 flights are in yellow. Flights of 17 July are highlighted in red.

each flight and ranged from 1.1 to 1.55 , depending on the encountered aerosol type. Total relative uncertainty of the derived total $\mathrm{BC}$ mass mixing ratio is about $30 \%$ (Laborde et al., 2012; Schwarz et al., 2017).

\subsection{Modeling strategy}

\subsubsection{WRF-Chem model setup}

In order to study the transport and processing of aerosols, regional chemical transport simulations are performed using the fully compressible mesoscale meteorological Weather Research and Forecasting model (Skamarock and Klemp, 2008) with chemistry modules (WRF-Chem Version 3.5.1) (Grell et al., 2005). The chemistry component is fully consistent with the meteorological part (Fast et al., 2006). The different schemes and parameterizations used in this work are summarized in Table 1. Land surface processes are resolved using the Noah Land Surface model scheme with four soil layers (Ek et al., 2003). PBL processes are parameterized according to the Mellor-Yamada-Janjic local scheme (Janjic, 1994). It is coupled to a surface layer based on MoninObukhov with Zilitinkevich thermal roughness length and standard similarity functions from look-up tables. We use the Morrison two-moment microphysics scheme (Morrison et al., 2009). To represent the effects of subgrid-scale convective processes on the grid variables, we use the Kain-Fritsch convective implicit parameterization (Kain, 2004), which has been recently improved by Berg et al. (2013) (details below) The shortwave and longwave radiation schemes are from the 
Table 1. Schemes and parameterizations used for the WRF-Chem simulations.

\begin{tabular}{ll}
\hline Physical process & WRF-Chem option \\
\hline Planetary boundary layer & Mellor-Yamada-Janjic (Janjic, 1994) \\
Surface layer & Monin-Obukhov \\
Land surface & Noah Land Surface model (Ek et al., 2003) \\
Microphysics & Morrison two-moment (Morrison et al., 2009) \\
Shortwave radiation & RRTMG (Iacono et al., 2008) \\
Longwave radiation & RRTMG (Iacono et al., 2008) \\
Cumulus parameterization & Kain-Fritsch-CuP (KFCuP) (Berg et al., 2013, 2015) \\
Photolysis & Fast-J (Wild et al., 2000) \\
Gas-phase chemistry & CBM-Z (Zaveri and Peters, 1999) \\
Aerosol model & MOSAIC eight bins with aqueous chemistry (Zaveri et al., 2008) \\
\hline
\end{tabular}

RRTMG model (Iacono et al., 2008). The Fast-J photolysis scheme (Wild et al., 2000) is coupled with hydrometeors as well as aerosols.

The model domain is set up on a polar stereographic grid of $8800 \mathrm{~km} \times 8800 \mathrm{~km}$ (Fig. 1). It has a horizontal resolution of $40 \mathrm{~km}$ and 50 vertical levels up to $50 \mathrm{hPa}$. The lowest vertical grid spacing is about $25 \mathrm{~m}$. The simulation uses a model time step of $180 \mathrm{~s}$, begins at 00:00 UTC on 4 July 2012 (after 3 days of spinup) and ends at 00:00 UTC on 21 July 2012. Initial conditions and lateral boundaries of the meteorological fields are provided by National Centers for Environmental Prediction (NCEP) Global Forecast System (GFS) Final Analysis (FNL) $1^{\circ}$ resolution data, which has 26 pressure levels and is updated every $6 \mathrm{~h}$. The simulations are also initialized with NCEP-archived $0.5^{\circ}$ sea-surface temperatures fields (updated every $6 \mathrm{~h}$ ) and sea-ice data (updated every day). The modeled horizontal wind components, atmospheric temperature and humidity are nudged towards the 6-hourly NCEP/FNL reanalysis data (Stauffer and Seaman, 1990) above the PBL. The offline global chemical transport model MOZART-4 (the Model for Ozone and Related Chemical Tracers) provides initial and spatially and temporally (6-hourly) varying boundary conditions for chemistry and aerosol species (Emmons et al., 2010).

In this study, the MOSAIC (Model for Simulating Aerosol Interactions and Chemistry) aerosol model (Zaveri et al., 2008) coupled with the CBM-Z (Carbon Bond Mechanism) photochemical mechanism (Zaveri and Peters, 1999) is used. MOSAIC employs a sectional approach to simulate size distributions of a wide number of internally mixed aerosol components (BC, organics, sea salt, sulfate, nitrate, ammonium, dust, and others). The size distribution for each species is divided into eight size bins between $39 \mathrm{~nm}$ and $10 \mu \mathrm{m}$. The MOSAIC aerosol scheme includes physical and chemical processes of nucleation, condensation, coagulation, aqueousphase chemistry, and water uptake by aerosols. It is also coupled to the microphysics and cumulus schemes, as well as to the shortwave and longwave radiation schemes.

Aerosol dry deposition is modeled using the "Resistance in Series Parameterization" (Wesely and Hicks,
2000). Wet removal of aerosols by grid-resolved stratiform clouds/precipitation includes in-cloud and below-cloud removal by rain, snow, and graupel by Brownian diffusion, interception, and impaction mechanisms, following Easter et al. (2004) and Chapman et al. (2009). Gustafson et al. (2007) included aerosol-cloud interactions in the model to calculate the activation and resuspension between dry aerosols and cloud droplets. Furthermore, WRF-Chem model is now able to represent aerosol and trace gases within subgrid-scale convective clouds. Berg et al. (2015) indeed included fractional coverage of active and passive clouds, vertical transport, activation and resuspension, wet removal, and aqueous chemistry for cloud-borne particles. This new treatment, coupled to MOSAIC aerosol scheme, is important in our Arctic-scale modeling study to investigate the cloud effects on aerosol within parameterized shallow and deep convective clouds.

\subsubsection{Emissions}

Our simulations use daily, $1 \mathrm{~km}$ horizontal resolution fire emissions from the Fire INventory from NCAR (FINN-v1) (Wiedinmyer et al., 2011), based on fire count information from the MODIS (Moderate Resolution Imaging Spectrometer) instrument. Appropriate fire properties are obtained from a synergy between remote sensing observations, land use and carbon fuel datasets to determine in which columns the fires are located and the plume rise is simulated explicitly, accounting for thermal buoyancy associated with fires and local atmospheric stability (Freitas et al., 2007; Grell et al., 2011; Sessions et al., 2011). Anthropogenic emissions are taken from the HTAPv2 (Hemispheric Transport of Air Pollution version 2) $0.1^{\circ} \times 0.1^{\circ}$ inventory (http://edgar.jrc.ec.europa. eu/htap_v2/). Volatile organic compounds (VOCs) are given as a bulk VOC mass and distributed into CBM-Z emission categories assuming the speciation reported by Murrells et al. (2010). Hourly and weekly variability of anthropogenic emissions is applied for each emission sector (van der Gon et al., 2011). Flaring emissions are from the ECLIPSE (Evaluating the CLimate and Air Quality ImPacts of Short-livEd 
Pollutants) inventory (Stohl et al., 2015). Sea salt and soilderived (dust) aerosol emissions are incorporated into WRFChem (Shaw et al., 2008). Biogenic emissions are calculated online following MEGAN (Model of Emissions of Gases and Aerosols from Nature) (Guenther et al., 2006).

\subsubsection{Model simulations}

The fine-scale structure of the Arctic atmosphere (e.g., due to the thermal stratification) poses a major problem for atmospheric transport model simulations. Here we run the WRFChem on a polar-stereographic projection at relatively high horizontal $(40 \mathrm{~km})$ and vertical (50 levels up to $50 \mathrm{hPa}$ ) resolution to adequately represent the actual structure of the Arctic atmosphere, avoiding an overly rapid diffusion and decay along the boundaries of advected plumes (Rastigejev et al., 2010). A total of nine simulations are conducted: a baseline WRF-Chem simulation (BASE) and eight sensitivity tests to investigate the effect of several processes and emission sources on $\mathrm{BC}$ transport to the Arctic: a run without biomass burning emissions (NoFire), a run without anthropogenic emissions (NoAnthro), a run without emissions from flaring activities (NoFlr), a run without dry deposition (NoDry), a run without wet deposition in grid-scale clouds (NoWet), a run without wet deposition in parameterized cumulus clouds (NoWetCu), and a run without wet removal in any clouds (NoWetAll). An additional simulation (Run100) similar to the BASE simulation, but at a coarser resolution $(100 \mathrm{~km})$ is also performed to study the influence of horizontal resolution on the transport and deposition of carbonaceous aerosols. The list of the WRF-Chem runs performed is summarized in Table 2.

\subsubsection{FLEXPART-WRF}

We use the Lagrangian particle dispersion model FLEXPART-WRF (Fast and Easter, 2006; Brioude et al., 2013) to assess pollution transport and dispersion from individual sources and to identify the origins of measured pollution plumes during the ACCESS campaign. FLEXPART-WRF is derived from the FLEXPART dispersion model (Stohl et al., 2005), driven by meteorological fields simulated by WRF. We use FLEXPART-WRF in backward mode to study source-receptor relationships: 10000 particles are released at a receptor point and are transported backward in time using the meteorological fields from the BASE run. Source-receptor relationships are quantified by calculating the potential emission sensitivities (PES), which represent the amount of time spent by the particles in every grid cell. In this paper, meteorological variables are interpolated in time and space over trajectories from the WRF runs. FLEXPART-WRF is therefore useful to identify the origins and transport pathways of pollution plumes observed during the ACCESS campaign and to derive precipitation and deposition efficiencies along those transport pathways (Sect. 5).

\section{Model validation}

\subsection{Meteorological parameters}

To evaluate the skill in the modeled weather and transport patterns predictions, model results are first compared to ACCESS observations in terms of potential temperature, relative humidity (RH), wind speed and wind direction. The model outputs available at hourly intervals are linearly interpolated in latitude, longitude, altitude and time, every minute along the flight track. The ensemble of key observed and simulated meteorological parameters interpolated along the 14 flight tracks are then gathered to compute vertical profiles. The comparison with Falcon observations is shown in Fig. 2. The predicted temperature is in very close agreement with airborne measurements, with only a small negative bias (about $-1 \mathrm{~K})$ at high altitudes. The modeled wind direction also matches the observations closely, with a slight positive normalized mean bias (NMB $<6 \%)$ in the boundary layer. We note however that statistical performances for wind direction should be taken with caution as they are derived from a vector quantity. The simulated wind speed shows good agreement with a correlation coefficient of $R^{2} \simeq 0.866$, although a slightly negative bias (lower than $3 \%$ ) at altitudes above $6 \mathrm{~km}$. The water vapor mixing ratio and the resulting $\mathrm{RH}$ are also well reproduced by the model with high correlation coefficients (Table 3). Overall WRF-Chem shows appreciable skill in capturing the variability seen in the observations, suggesting that the large-scale transport patterns and major aspects of flow conditions are well represented in the WRF simulations for this campaign.

\subsection{Trace gases and aerosols}

Figure 3 shows the vertical profiles of the $\mathrm{CO}$ and $\mathrm{BC}$ mixing ratios measured during the ACCESS campaign and simulated by WRF-Chem (BASE and Run100 simulations). On average, the ACCESS measurements show enhanced $\mathrm{BC}$ and $\mathrm{CO}$ concentrations between 6 and $9 \mathrm{~km}$ altitude. The two measured profiles are well correlated with maximum $\mathrm{CO}$ values of $200 \mathrm{ppbv}$ at $7-8 \mathrm{~km}$, associated with elevated $\mathrm{BC}$ values reaching $25 \mathrm{n} \mathrm{kg}^{-1}$. The corresponding mean values for $\mathrm{CO}$ and $\mathrm{BC}$ in this altitude range are $135 \mathrm{ppbv}$ and $12 \mathrm{ng} \mathrm{kg}^{-1}$, respectively. The small underestimation in $\mathrm{CO}$ between 6 and $9 \mathrm{~km}$ is a common feature observed by most models (Emmons et al., 2015; AMAP, 2015). Variability in models, run with the same emissions, appears to be driven by differences in chemical schemes influencing modeled $\mathrm{OH}$ and/or differences in modeled vertical export efficiency of $\mathrm{CO}$ (via frontal or convective transport) from mid-latitude source regions to the Arctic (Monks et al., 2015). A noticeable increase in ozone concentrations is also clearly seen at $7 \mathrm{~km}$, 
Table 2. List of WRF-Chem simulations performed.

\begin{tabular}{ll}
\hline Name & Description \\
\hline BASE & Baseline simulation at $40 \mathrm{~km}$ \\
NoFire & Run at $40 \mathrm{~km}$ without biomass burning emissions \\
NoAnthro & Run at $40 \mathrm{~km}$ without anthropogenic emissions \\
NoFlr & Run at $40 \mathrm{~km}$ without flaring emissions \\
NoDry & Run at $40 \mathrm{~km}$ without dry deposition \\
NoWet & Run at $40 \mathrm{~km}$ without wet deposition in grid-scale clouds \\
NoWetCu & Run at $40 \mathrm{~km}$ without wet deposition in parameterized cumulus clouds \\
NoWetAll & Run at $40 \mathrm{~km}$ without wet removal in any clouds \\
Run100 & Run at $100 \mathrm{~km}$ with the same vertical resolution as in the BASE run \\
\hline
\end{tabular}
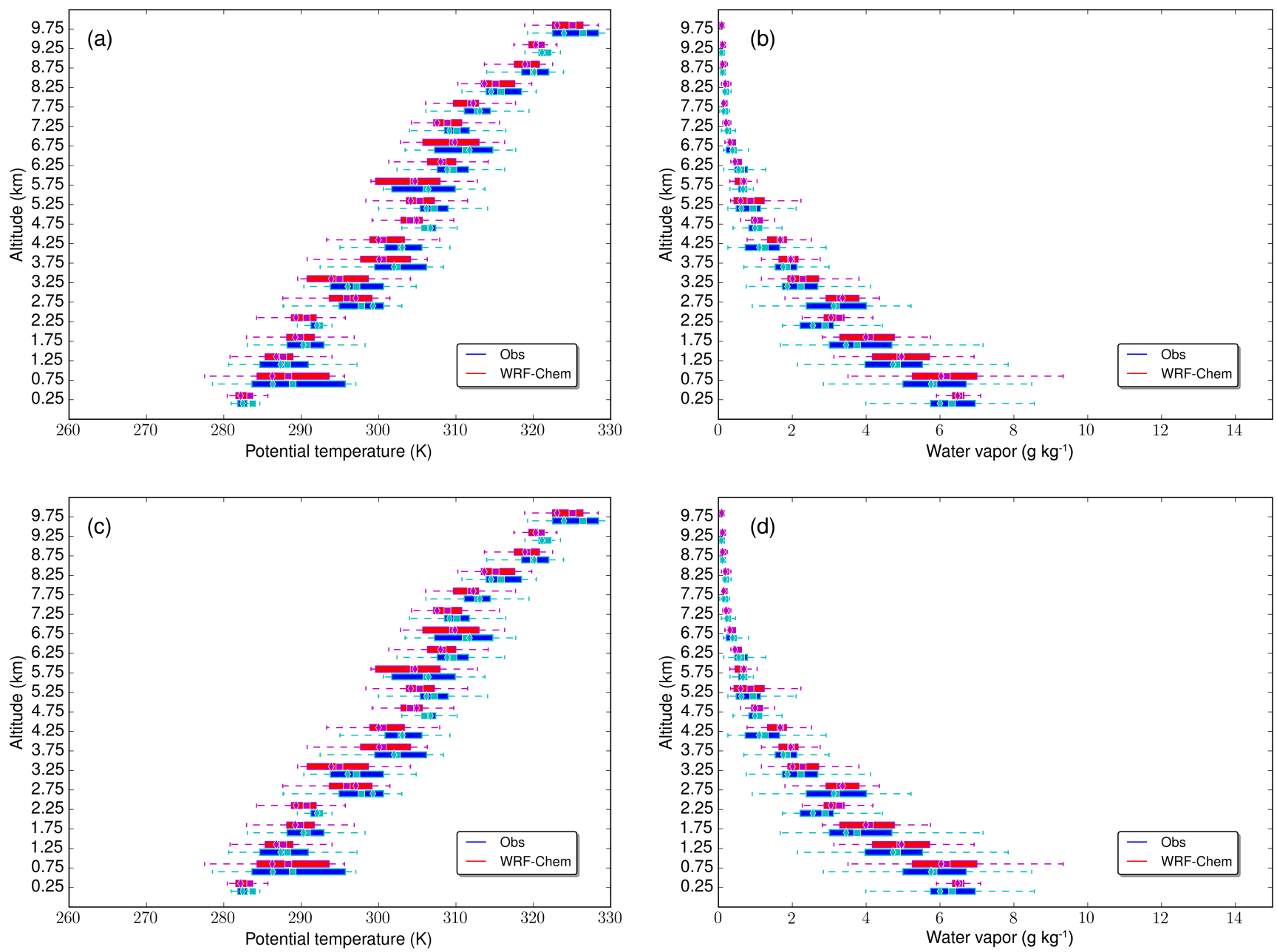

Figure 2. Vertical profiles of observed (blue) and modeled (red) (a) potential temperature (K), (b) water vapor mixing ratio $\left(\mathrm{g} \mathrm{kg}^{-1}\right)$, (c) wind speed $\left(\mathrm{m} \mathrm{s}^{-1}\right)$ and $(\mathbf{d})$ wind direction $\left(^{\circ}\right)$ interpolated along all the 14 Falcon flight tracks. Boxes represent the interquartile range, diamonds are the median values, squares show the means and whiskers show the minimum and maximum of the data.

with a mean value of $135 \mathrm{ppbv}$ (not shown). The vertical profiles of CO, BC and ozone suggest that, during summer 2012, pollution transported to the Arctic increased trace gases and aerosol mixing ratios in the middle and upper troposphere compared to typical clean background values (Roiger et al.,
2015). The statistical performance of the model in regards to the representation of key chemical species extracted along flight tracks are given in Table 3. The comparison of simulated $\mathrm{CO}$ (NMB $<1.5 \%$ ) against the Falcon flight measurements proves that the model predictions are able to capture 
Table 3. Performance statistics for meteorological variables and chemical species (BC, CO). For all flights, $R^{2}, \mathrm{MB}, \mathrm{RMSE}$ and NMB represent the Pearson correlation coefficient, the mean bias, the root-mean-square error, and the normalized mean bias, respectively.

\begin{tabular}{|c|c|c|c|c|}
\hline Variable (unit) & $R^{2}$ & MB & RMSE & $\mathrm{NMB}(\%)$ \\
\hline Pressure $(\mathrm{hPa})$ & 0.999 & 10.14 & 13.61 & 1.37 \\
\hline Potential temperature $(\mathrm{K})$ & 0.997 & -0.96 & 1.60 & -0.32 \\
\hline Relative humidity (\%) & 0.709 & 1.29 & 14.60 & 1.73 \\
\hline Wind speed $\left(\mathrm{ms}^{-1}\right)$ & 0.866 & -0.27 & 2.39 & -3.33 \\
\hline Water vapor mixing ratio $\left(\mathrm{g} \mathrm{kg}^{-1}\right)$ & 0.924 & 0.15 & 0.61 & 3.67 \\
\hline $\mathrm{BC}\left(\mathrm{ng} \mathrm{kg}^{-1}\right)$ & 0.468 & 1.58 & 7.44 & 27.30 \\
\hline $\mathrm{CO}$ (ppbv) & 0.524 & 1.47 & 17.63 & 1.49 \\
\hline
\end{tabular}
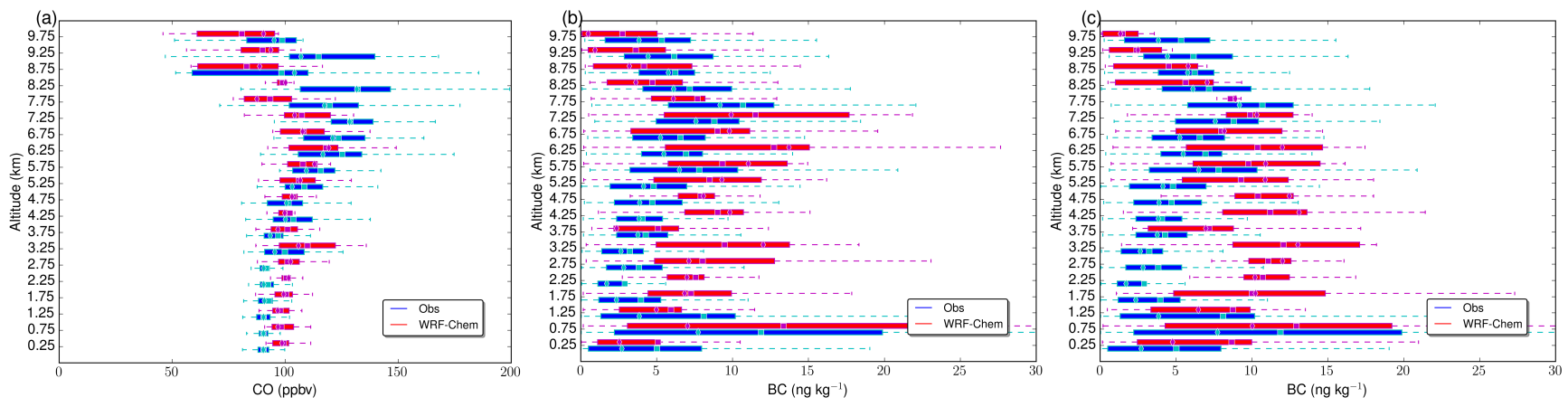

Figure 3. Vertical profiles of observed (blue) and modeled (red) mixing ratios of (a) CO (ppbv), (b) BC (ng kg ${ }^{-1}$ ) at a horizontal resolution $40 \mathrm{~km}$ (BASE), and (c) BC (ng kg-1) at a horizontal resolution $100 \mathrm{~km}$ (Run100) interpolated along all the 14 Falcon flight tracks. Boxes represent the interquartile range, diamonds are the median values, squares show the means and whiskers show the minimum and maximum of the data.

the magnitude and temporal variability seen in observed values. The model demonstrates reasonable skill in capturing the general structure of the vertical profile of $\mathrm{BC}$, but overestimates the $\mathrm{BC}$ mixing ratio in the mid-troposphere. The resulting mean bias on $\mathrm{BC}$ is $1.5 \mathrm{ng} \mathrm{kg}^{-1}$ and the corresponding normalized mean bias (27.3\%) is lower than the error on the SP2 instrument (30\%) and much lower than biases reported for most models in the Arctic region. Eckhardt et al. (2015) and AMAP (2015) indeed reported that BC concentrations in July-September are overestimated in the mean of intercompared models by $88 \%$. The mean profile of BC sampled during the ACCESS campaign is of the same order of magnitude as those reported by Breider et al. (2014) (25 $\mathrm{ng} \mathrm{m}^{-3}$ in July 2008) and by Schwarz et al. (2013) during the HIPPO (HIAPER Pole-to-Pole Observations) campaign at similar latitudes $\left(60-80^{\circ} \mathrm{N}\right)$ in the remote Pacific region (10-20 $\left.\mathrm{n} \mathrm{kg}^{-1}\right)$. In Sect. 4, we discuss the origin and transport of plumes leading to this noticeable increases of $\mathrm{CO}$ and $\mathrm{BC}$ between 6 and $9 \mathrm{~km}$ altitude, associated with higher ozone mixing ratios.

\subsection{Model resolution}

The result of the Run100 simulation is also shown in Fig. 3. The corresponding $\mathrm{BC}$ vertical profile shows the same en- hancement between 6 and $9 \mathrm{~km}$ as the BASE run, but it also clearly highlights a strong overestimation $(\times 3)$ in the midtroposphere $(1.5-5 \mathrm{~km})$. The CO concentrations are also enhanced in the Run 100 simulation by $4-5$ ppbv as compared to the BASE run. This suggests that, at a coarser resolution, the model is unable to resolve the fine structure of plumes transported aloft, illustrates the difficulty to represent the cloud and precipitation structures and points to the need for improved representation of $\mathrm{BC}$ processing in global models. More generally, global models are commonly run at horizontal and vertical resolutions that are inadequate for representing the actual structure of the Arctic atmosphere, mostly because of computational limited resources. Schwarz et al. $(2013,2017)$ studied the bias between BC measurements and the AeroCOM model suite in remote regions. Global models generally overestimated BC mass concentration, especially in the Arctic upper troposphere, where the overestimation was about a factor of 13 , suggesting that the aerosol lifetime and removal was not correctly in models. Model features that govern the vertical distribution and lifetimes of SLCFs in the Arctic atmosphere must still be improved (AMAP, 2015). Ma et al. (2013) showed that BC was better simulated with higher spatial resolution, and described that there is likely less wet removal at higher spatial resolution since aerosols and clouds do not overlap as much. In our study, at a hor- 

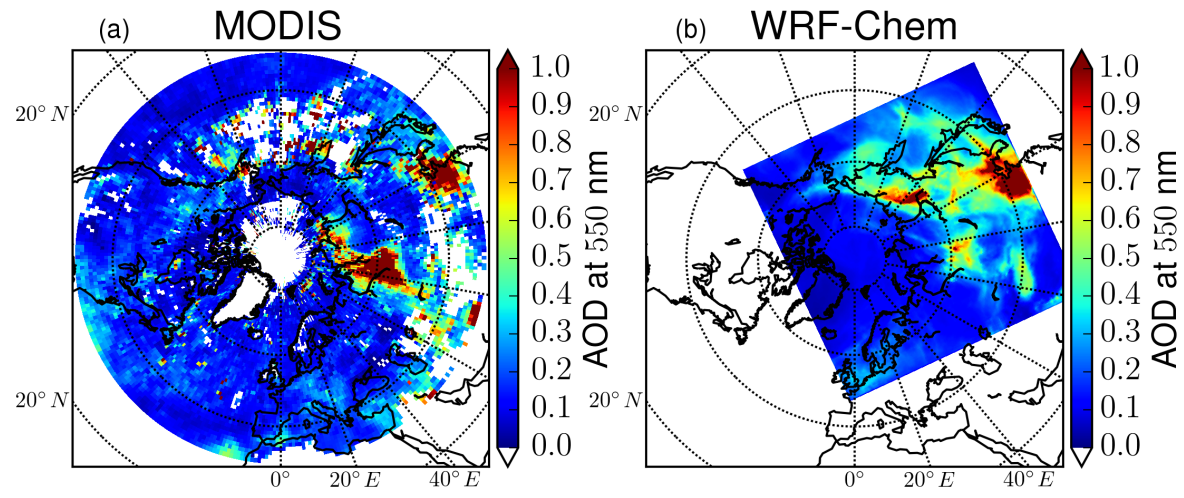

Figure 4. Aerosol optical depth (AOD) at $550 \mathrm{~nm}$ (a) measured by MODIS instrument aboard Aqua and (b) simulated by a Mie code in the WRF-Chem model, averaged between 4 and 21 July 2012. White areas in panel (a) indicate the presence of clouds, preventing the AOD retrieval.

izontal resolution of $40 \mathrm{~km}$, the model-to-observation comparison indicates that the WRF-Chem model correctly represents the transport pathways of pollution into the Arctic in summer from mid-latitudes and wildfire/biomass burning. At a finer resolution, the model is also able to better represent mean vertical motions associated with large-scale synoptic systems, i.e., conveyor belts, that lift PBL aerosols into the free troposphere. Resolution can therefore affect long-range transport, since it affects how high aerosols are lifted into the free troposphere.

\subsection{Aerosol optical depth}

To evaluate the total aerosol column simulated by WRFChem during the ACCESS campaign, we calculate the aerosol optical depth (AOD) at $550 \mathrm{~nm}$, defined as the integrated extinction coefficient over a vertical column of unit cross section, taking into account the attenuation of the radiance by aerosol scattering and absorption. This is compared to the AOD retrieved at the same wavelength by the MODIS instrument aboard Aqua satellite passing over the Equator in the afternoon. We average, over the period of the ACCESS campaign (4-21 July), daily observations of AOD obtained from MODIS level 3 products (Hubanks et al., 2008), accounting for missing observations primarily due to the presence of clouds within the column (Fig. 4). Note that the AOD retrieved from MODIS above Terra satellite is similar to that obtained from Aqua (not shown). In general, the model correctly represents the main features of the spatial distribution of AOD, including the large values over northeastern China and western Siberia. In China, high AODs reaching 2.3 (1.8 in the model) are linked to high pollution levels in the PBL combined with strong dust episodes. Over western Siberia, the extended area with substantially enhanced values of AOD (up to 2.5) is due to large fires (Ponomarev, 2013) and with a potential contribution from intense flaring activities where oil and gas resources are exploited (Stohl et al., 2013). The AOD is, however, underestimated by the model by $25 \%$ over this latter region. The model also highlights a strong signal over the Yakutsk region (maximum AOD of 2.2), which is less visible in the MODIS images due to the continuous presence of clouds in July 2012. This is due to intense biomass burning plumes at this period (Ponomarev, 2013). The plumes extend towards the east and above the Bering Strait. Other significant enhancements of modeled AOD (0.4-0.5) are also seen above northern India and the Pacific Ocean, corresponding to the outflow area of China. The good performance in representing the main features of AOD distribution, especially in eastern Asia and western Siberia, gives good confidence in the model to transport plumes to the Arctic. The underestimation above northern Russia indicates that the transport of plumes from that area should be considered with caution. Nevertheless, due to the large amount of precipitation in this area (Sect. 3.5), the potential impact of this source area is reduced.

\subsection{Precipitation}

The lofting of BC can occur isentropically at low RH or can be caused by rapid ascent and heavy precipitation (Matsui et al., 2011). Studying precipitation during transport is therefore crucial and it needs to be modeled correctly to understand the role of wet removal of aerosols. Daily GPCP (Global Precipitation Climatology Project) precipitation data are used to assess the reproducibility of precipitation in the BASE simulation. Here we use GPCP data (version 1.2) at $1^{\circ}$ resolution, retrieved from a combination of satellite observations and rain gauge measurements (Huffman et al., 2001). Model estimates of rainfall are interpolated every day to the GPCP $1^{\circ}$ grid and then averaged between 4 and 21 July to give an assessment of the mean precipitation during the ACCESS campaign. The WRF-Chem simulation overall reproduces the spatial distribution of the observed precipitation reasonably well (Fig. 5), with highest precipitation intensity over Southeast Asia (South Korea and Japan) with about $17 \mathrm{~mm} \mathrm{day}^{-1}$, high values over northern China and Mongolia 

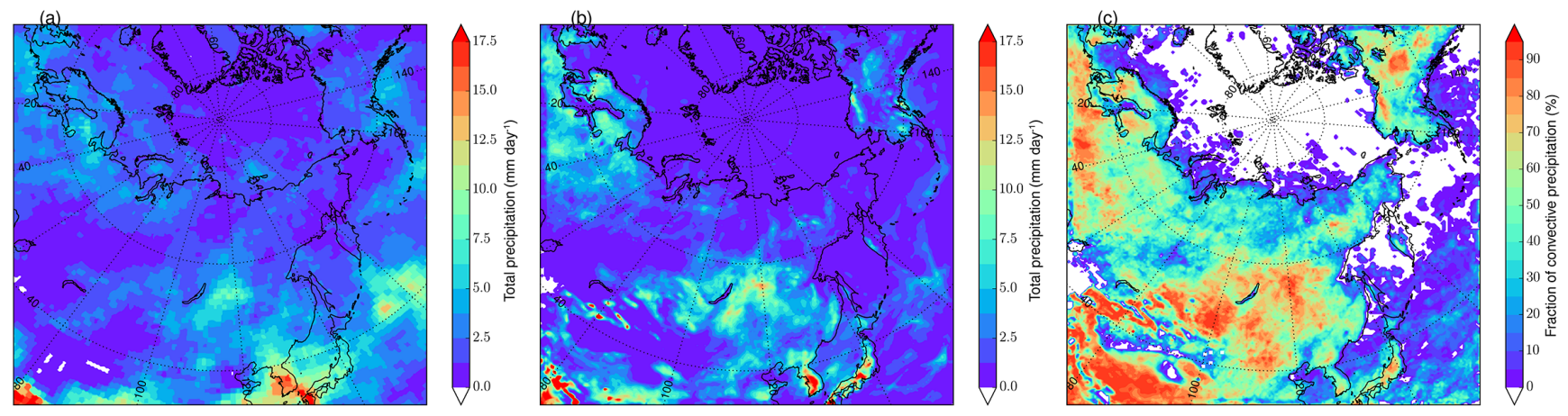

Figure 5. Average precipitation from period 4-21 July (a) obtained from $1^{\circ}$ daily GPCP data and (b) simulated by WRF-Chem. The fraction of convective precipitation is shown in panel (c).

and in the vicinity of Lake Baikal (9-11 mmday ${ }^{-1}$ ) or over the Pacific Ocean due to storm tracks and associated WCBs $\left(10-13 \mathrm{~mm} \mathrm{day}^{-1}\right)$. Modest values are detected over Europe with $5-8 \mathrm{~mm} \mathrm{day}^{-1}$. The model nevertheless overestimates the precipitation intensity over southern Russia close to Lake Baikal and over Europe (by $20 \%$ ) and underestimates values over the Pacific Ocean. Over Siberia and central Arctic the precipitation intensity is low $\left(1-3 \mathrm{mmday}^{-1}\right)$. The highest values of rainfall are correlated with high convective precipitation fractions (Fig 5), reaching 60 to $90 \%$ over land. Over the oceans and northern Russia the main contribution is from non-convective precipitation (e.g., drizzle).

\subsection{Cloud vertical distributions}

Prediction of Arctic clouds (regional extent and heights) remains a challenge but is also crucial, since the vertical distribution of clouds as well as the state of cloud microphysics is important to understand how models assess the wet removal of aerosols. To evaluate the vertical distributions of clouds in our BASE simulation, we use the DARDARMASK v1 data set, which employs a combination of the CloudSat and CALIPSO (Cloud-Aerosol Lidar and Infrared Pathfinder Satellite Observations) products (Delanoë and Hogan, 2010). To retrieve cloud-phase properties, the algorithm uses the $94 \mathrm{GHz}$ radar reflectivity from CloudSat, the lidar backscatter coefficient at $532 \mathrm{~nm}$ and vertical feature mask from CALIPSO, as well as ECMWF (European Centre for Medium-Range Weather Forecasts) thermodynamic variables. A range of categories is returned from the DARDARMASK: clear, ground, stratospheric features, aerosols, rain, supercooled liquid water, liquid warm, mixed-phase and ice. The algorithm also includes an uncertain classification, in regions where the lidar signal is heavily attenuated or is missing. In this study, we use a simple DARDAR-MASK simulator for WRF-Chem enabling a clear comparison between the model and satellite observations. Mass mixing ratios of liquid water, ice crystals, rain, graupel and snow, as well as the temperature, are interpolated in time and space from the model along each CALIPSO or CloudSat track passing through the WRF-Chem domain during the simulation (421 July 2012). The observed and simulated masks are then temporally averaged at each altitude bin for each cloud-phase category: uncertain, ice, mixed-phase (ice and supercooled water), liquid warm, supercooled water and rain. The result is a mean vertical profile for each category and is represented in Fig. 6. Not surprisingly, the cloud fraction is more important in the lowest layers than at higher altitudes, as the source of water in clouds is the evaporation from the Arctic Ocean and the humid soil. In the upper troposphere, the fraction of occurrence is $20 \%$ both in DARDAR and WRF-Chem, and clouds are composed only of ice crystals. This is directly liked to the temperature of clouds, below $-40{ }^{\circ} \mathrm{C}$ at those altitudes. The ability of the model to represent those high clouds is excellent. In the PBL, the cloud fraction is larger (between 20 and 35\% if the uncertain category is not taken into account) and is dominated by liquid warm and rain. The main discrepancy between the model and the satellite observations can be ascribed to the uncertain cloud type. When the cloud type is classified as uncertain because the lidar signal is extinguished or too attenuated below optically thick clouds, the model generally predicts no cloud. The model slightly overestimates the fraction of clouds containing supercooled water in the PBL (by $2 \%$ ), whereas this fraction is underestimated in the mid-troposphere. The model also slightly underestimates the fraction of ice and supercooled droplets in the upper troposphere. If we do not consider the uncertain class, the result of the WRF-Chem model shows appreciable skill in capturing the average vertical distribution of cloud phases. In particular, the vertical distribution of the liquid warm and rain categories is well reproduced. This is very promising in simulating the wet deposition efficiency of aerosols in plumes transported to the Arctic region. 


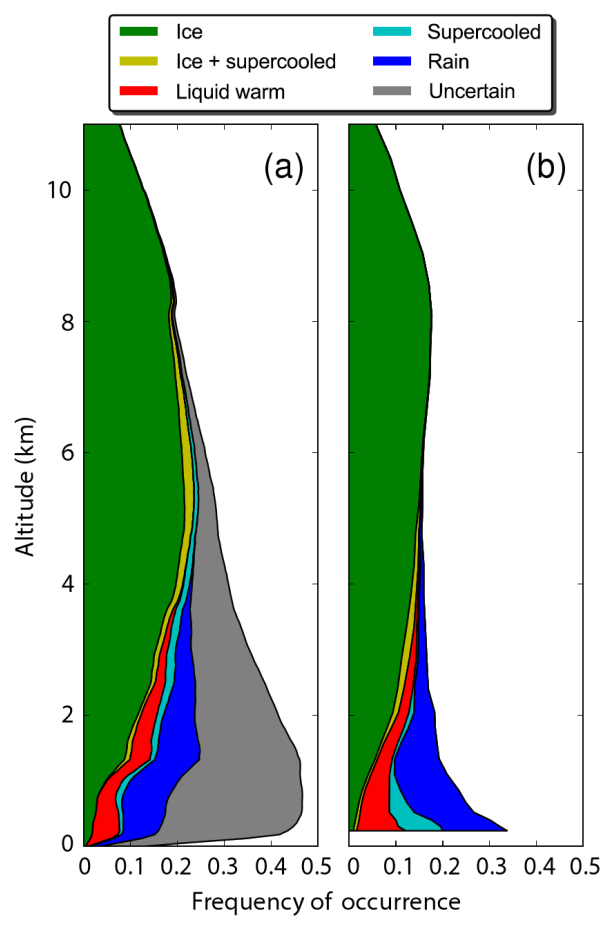

Figure 6. Mean vertical profiles of the different cloud-phase categories (a) returned from the DARDAR-MASK and (b) simulated by the WRF-Chem model between 4 and 21 July.

\section{Source attribution of $\mathrm{BC}$ particles}

\subsection{Export processes}

To identify the sources and mechanisms of pollution BC export to the Arctic, we compute the horizontal poleward eddy heat flux at the $850 \mathrm{hPa}$ level using the model (Fig. 7). Regions with large values of the horizontal poleward eddy heat flux generally illustrate the activity of migratory cyclones and may reflect strongly ascending moist airstreams (WCBs) in extratropical cyclones that rise from the PBL to the free troposphere (FT) on short timescales (1 or 2 days) (Eckhardt et al., 2004). The horizontal poleward eddy heat flux is calculated as $\overline{v^{\prime} \theta^{\prime}}$, where the overbar denotes time-averaging over the ACCESS period (4-21 July 2012). Because the timescale of the migratory cyclones is about 1 week, $v^{\prime}$ and $\theta^{\prime}$ are the instantaneous deviations from the 5-day running means of the meridian wind component and the potential temperature, respectively. This eddy heat flux is computed at each grid point of the WRF-Chem simulation. Large values of eddy heat transport are found over the West Siberian Plain $\left(60-70^{\circ} \mathrm{N}, 40-80^{\circ} \mathrm{E}\right)$ extending above the Barents Sea, over the Sakha (Yakutia) Republic $\left(65-70^{\circ} \mathrm{N}, 110-150^{\circ} \mathrm{E}\right)$ and finally over the Pacific storm track around northern Japan. If those regions are located in the vicinity of $\mathrm{BC}$ sources, they are likely to contribute to export pollution to the Norwegian Arctic, including areas sampled by the Falcon.
In Fig. 7, the horizontal distribution of the mean upward $\mathrm{BC}$ mass fluxes averaged over the ACCESS period $(\overline{[\mathrm{BC}] w})$, where $w$ denotes the vertical velocity) is also represented at $700 \mathrm{hPa}$. Three regions with strong upward BC fluxes can be identified: central and northeastern China $\left(30-45^{\circ} \mathrm{N}, 110\right.$ $\left.120^{\circ} \mathrm{E}\right)$, south of the Krasnoyarsk region $\left(50-60^{\circ} \mathrm{N}, 80\right.$ $\left.100^{\circ} \mathrm{E}\right)$ and Yakutia $\left(60-68^{\circ} \mathrm{N}, 125-150^{\circ} \mathrm{E}\right)$. Those regions characterized by a strong ascent of $\mathrm{BC}$ mass fluxes are also co-located with areas presenting large values for the convergence of horizontal BC flux in the PBL, defined here as the $700-1000 \mathrm{hPa}$ layer and large values for the divergence of horizontal BC flux in the FT, defined here as the $700-200 \mathrm{hPa}$ layer (Fig. 7). They illustrate the locations of source regions for $\mathrm{BC}$ emissions and the divergences represent the horizontal transport of $\mathrm{BC}$ emitted from those source regions to the surrounding regions (Oshima et al., 2013). Convergence of $\mathrm{BC}$ flux in the lowest layers can indeed uplift air parcels from the surface to the FT, which are then exported to outflow regions. A good spatial correlation is also observed with the spatial distribution of AOD (Fig. 4), illustrating that the main emission areas present a significant fraction of carbonaceous aerosols. BC emitted from central and northeastern China is mostly of anthropogenic origin, whereas the two other regions (south of the Krasnoyarsk region and Yakutia) are colocated with intense biomass burning sources, explaining the strong values of the upward $\mathrm{BC}$ flux. Aerosols and $\mathrm{CO}$ emitted from those source regions may potentially be exported towards the Arctic through the areas presenting large horizontal poleward eddy heat flux: the Sakha (Yakutia) Republic $\left(65-70^{\circ} \mathrm{N}, 110-150^{\circ} \mathrm{E}\right)$ and the Pacific storm track. We also note that the source of $\mathrm{BC}$ identified in western Siberia is also partly located in the region where the Russian oil and gas flaring emissions are very high and along the main low-level pathway of air masses entering the Arctic (Stohl et al., 2013). They may be exported towards the Arctic through the region with high values of $\overline{v^{\prime} \theta^{\prime}}$, extending above the Barents Sea. Anthropogenic emissions in Europe may also be exported to the Arctic (large values of $\overline{v^{\prime} \theta^{\prime}}$ in northern Norway) but to a lower extent since the corresponding horizontal and vertical mass fluxes of $\mathrm{BC}$ are low in summer.

\subsection{Plume identification}

As indicated in Sect. 2.1, the two flights of 17 July (namely flight $17 \mathrm{a}$ in the morning and flight $17 \mathrm{~b}$ in the afternoon) were specifically dedicated to plumes transported in the upper troposphere from boreal and Asian sources to the Arctic region. Data obtained during these flights are thus the most relevant for the study of $\mathrm{BC}$ transport to the Arctic. The vertical cross sections of $\mathrm{CO}$ and $\mathrm{BC}$ interpolated from the WRFChem BASE simulation onto the two flight tracks of 17 July are shown in Fig. 8. In situ measurements of these variables are also represented. The horizontal and vertical variabilities of the $\mathrm{CO}$ and $\mathrm{BC}$ enhancements ascribed to different source regions can be distinguished from the modeled time- 
(a) Pressure level $=850 \mathrm{hPa}$
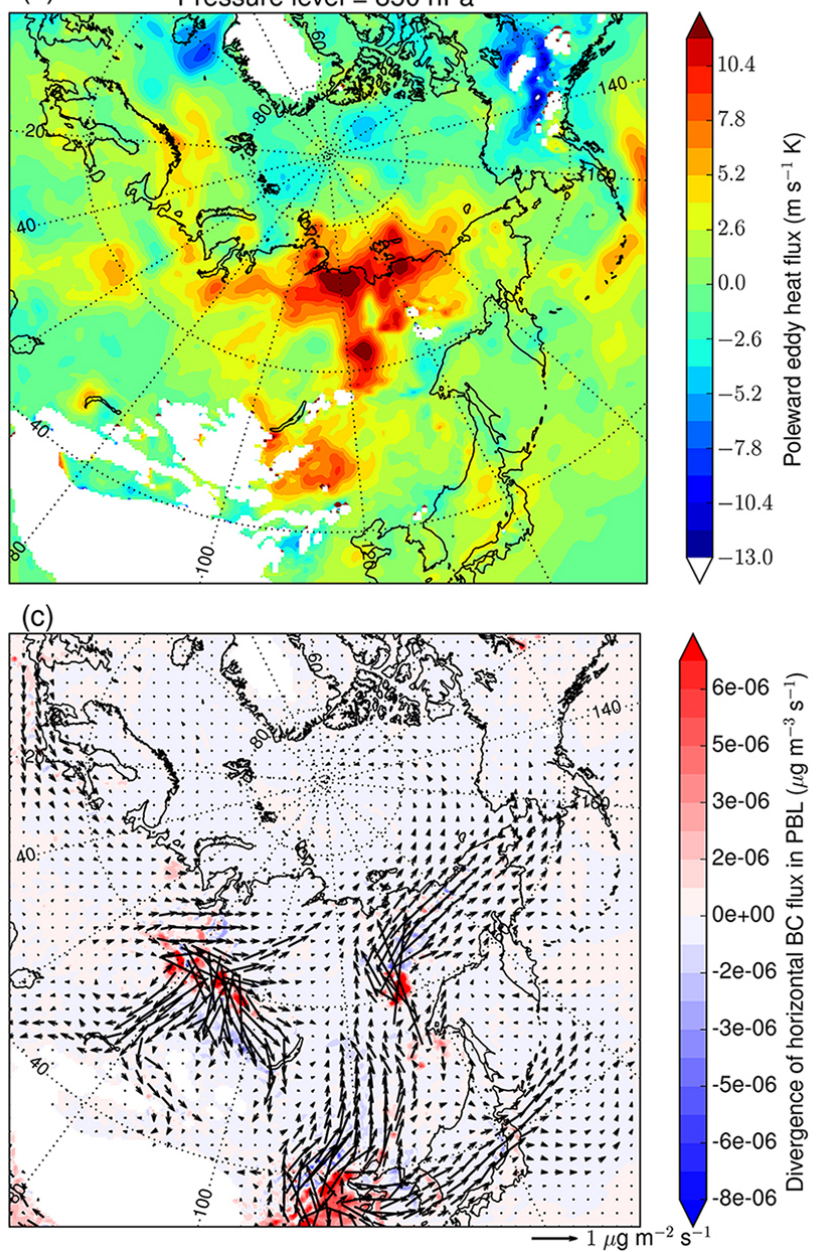

(b) Pressure level $=700.0 \mathrm{hPa}$
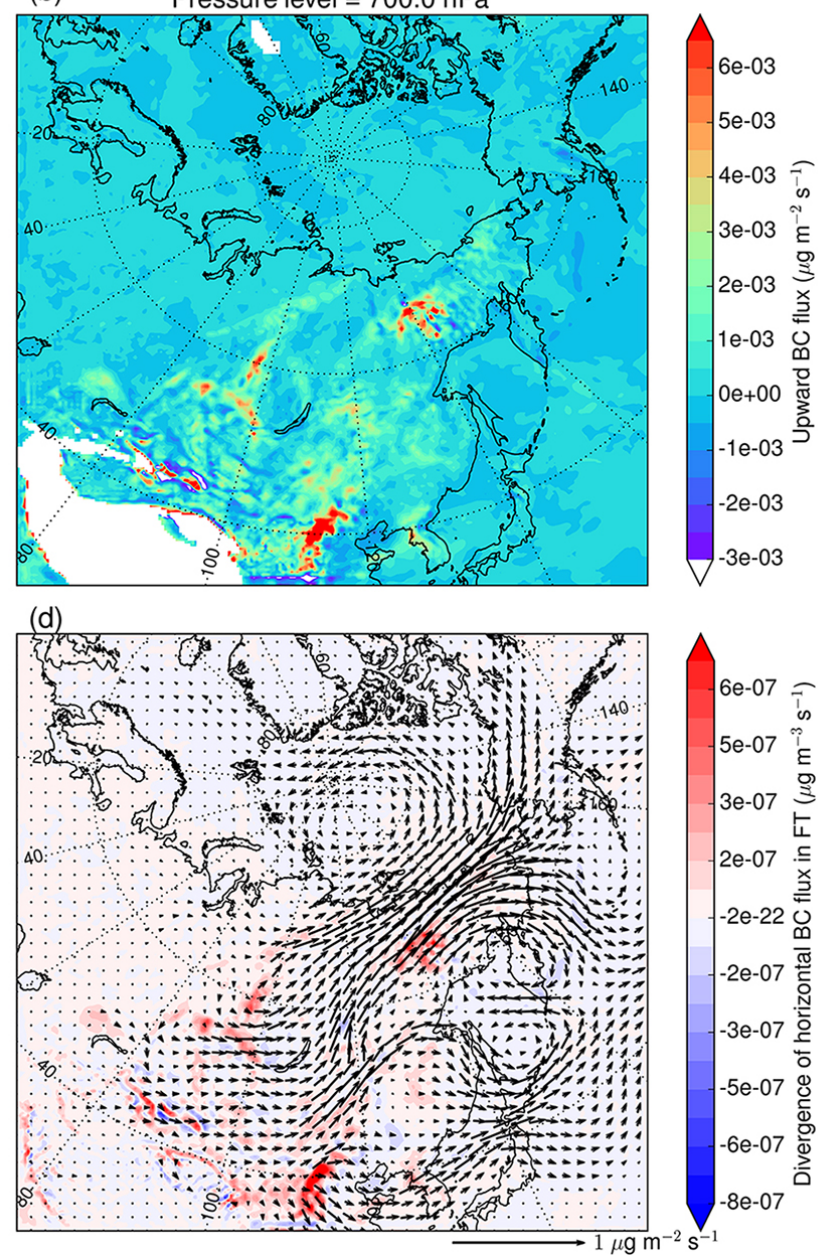

Figure 7. Time-averaged (a) horizontal poleward eddy heat flux $\overline{v^{\prime} \theta^{\prime}}$ at the $850 \mathrm{hPa}$ level, (b) upward mass flux of $\mathrm{BC} \overline{[\mathrm{BC}] w}$ at the $700 \mathrm{hPa}$ level, and divergence of the horizontal mass flux of BC integrated over (c) the PBL and (d) the free troposphere (FT) during the ACCESS period in the WRF-Chem BASE simulation. Regions without data in white have a high orography (surface pressure below the plotted level). Vectors representing the time-averaged horizontal mass flux of BC integrated over the PBL and FT during the ACCESS period are shown in panels (c) and (d) respectively, as well as the scaling near the lower right corner.

altitude cross sections along the selected flight tracks. The Falcon transected pollution plumes located between Andøya $\left(69.1^{\circ} \mathrm{N}, 15.7^{\circ} \mathrm{E}\right)$ and Spitsbergen $\left(78.9^{\circ} \mathrm{N}, 18.0^{\circ} \mathrm{E}\right)$ during flight $17 \mathrm{a}$ and sampled the same plumes again during flight $17 \mathrm{~b}$ before returning to Andøya. The model simulates various $\mathrm{CO}$ enhancements during each flight period. Increases in modeled BC mixing ratios are well co-located with those $\mathrm{CO}$ enhancements. The PV (potential vorticity) vertical cross section suggests that all those enhancements are in the troposphere: at the time of the flights, the stratospheric air masses are confined in regions with potential temperature larger than $310 \mathrm{~K}$, with a fold between 09:30 and 13:30 UTC, bringing stratospheric intrusions down to $310 \mathrm{~K}$. In the upper troposphere, the model predicts three periods of enhanced $\mathrm{CO}$ and $\mathrm{BC}$ during each flight, near the $310 \mathrm{~K}$ isentrope (altitude between 6 and $8 \mathrm{~km}$ ). In this altitude range, when the Falcon crosses the plumes predicted by the model, the instruments also detect higher concentrations of $\mathrm{CO}$ and BC. WRF-Chem however underestimates the magnitude of the mixing ratios of carbon monoxide in the peaks, reaching $210 \mathrm{ppbv}$. This is mostly due to numerical diffusion caused by the finite-difference method applied to the advection equation on the model grid. In the model, the gradients are simply taken along coordinate surfaces and hence are imperfectly described. A sixth-order numerical diffusion is used in our simulations. The $\mathrm{CO}$ underestimation can be also due to the fact that the Falcon sampled the southern edge of a larger and more intense plume located farther north before returning to Andenes (Roiger et al., 2015). The underestimation of $\mathrm{CO}$ can also partly be ascribed to too low emissions or problems in modeling $\mathrm{OH}$. This plume is shifted towards the north by $40 \mathrm{~km}$ in the model simulation, explaining the strong 

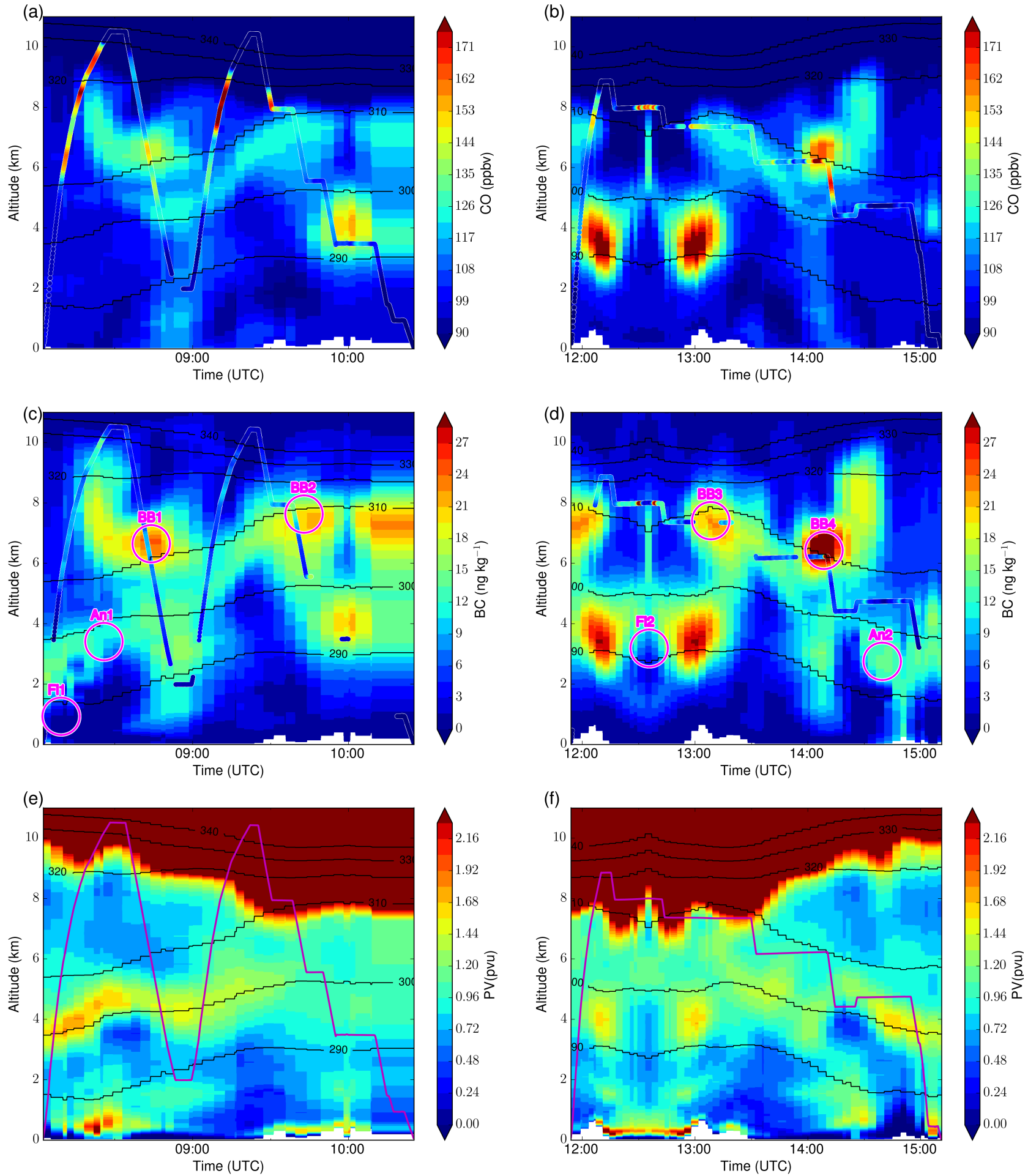

Figure 8. Vertical cross sections of (a, b) CO mixing ratio, (c, d) BC mixing ratio, and (e, f) PV along Falcon flight tracks on 17 July 2012 extracted from WRF-Chem between the island of Andøya and the Svalbard archipelago. In situ measurements aboard the Falcon averaged using a 2 min running mean are shown in each panel with colored dots, using the same color scale. Only BC values outside of clouds are reported. Black solid lines represent the dry isentropes between 290 and $340 \mathrm{~K}$. Magenta circles highlight the air masses discussed in Sect. 4.4. 
underestimation of the model at 09:15 UTC. In terms of BC, the agreement between WRF-Chem and the SP2 instrument is reasonable. Inside the plumes, values of $20-25 \mathrm{ng} \mathrm{kg}^{-1}$ are reported, with peak values larger than $30 \mathrm{ng} \mathrm{kg}^{-1}$. In the midtroposphere, $\mathrm{CO}$ and $\mathrm{BC}$ concentrations are also significantly increased sporadically in the band delimited by the 290 and $300 \mathrm{~K}$ isentropes (between 2 and $4 \mathrm{~km}$ ) with values reaching $180 \mathrm{ppbv}$ and $30 \mathrm{ng} \mathrm{kg}^{-1}$, respectively.

\subsection{Contribution from the different sources}

To understand the contributions of the different source emissions (anthropogenic, biomass burning and flaring) to the BC transported to the region of the flights, we use the difference between the BASE run and the NoAnthro, NoFire, and NoFlr simulations. Model results from each run are interpolated in time and space to the position of the Falcon during the two flights on 17 July. The relative contribution of each source to total $\mathrm{BC}$ is obtained by dividing by the results derived from the BASE simulation. Figure 9 shows the time-altitude cross sections of the relative contributions of $\mathrm{BC}$ concentrations due to the different emission sources. The two vertical cross sections clearly underline that the mass mixing ratio of $\mathrm{BC}$ is strongly dominated by the fire contribution, which is generally larger than $80 \%$ at all altitudes and times, and often larger than $90 \%$. We note two exceptions to the dominance of fires. In the vicinity of the Norwegian coast, i.e., just after take-off from Andenes before 09:00 and on the way back to Norway after 14:00 UTC, a strong influence of anthropogenic sources (about $85 \%$ ) is clearly identified between 2 and $4 \mathrm{~km}$, and to a lesser extent in the PBL, where a weaker contribution of Norwegian flares is predicted (40-70\%). A second zone where the influence of fires is low (below 15\%) is detected in the mid-troposphere $(2-5 \mathrm{~km})$ between $12: 30$ and 13:00 UTC. In this region, the contribution of flaring emissions from Siberian oil exploration is dominant, about $80 \%$.

In Sect. 4.2, we identified significant enhancements in $\mathrm{CO}$ and $\mathrm{BC}$ between 6 and $8 \mathrm{~km}$. According to Fig. 9, these plumes originate from large biomass burning sources in Siberia. In WRF-Chem, the fire emission heights are determined by the online plume rise injection model (Grell et al., 2011). These emissions may then be lofted to the faster winds of the free atmosphere. We should note that in this altitude range $(5-10 \mathrm{~km})$, the contribution of anthropogenic sources is weak (maximum $15 \%$ ) but not zero. There is likely a small influence of the vertical transport by continental convective lifting over Asia in summer and frontal lifting due to midlatitude cyclones. The transport pathways from the different source regions to the Arctic is discussed in Sect. 4.4. In the mid-troposphere $(2-4 \mathrm{~km})$, the $\mathrm{CO}$ and $\mathrm{BC}$ concentrations have also increased due to the influence of fires, except in the vicinity of the northern Norwegian coast, where the impact of anthropogenic sources is larger. The flaring emissions play a very localized role in the area of the flights and do not lead to any noticeable increase in $\mathrm{CO}$ or BC.

\subsection{Transport pathways}

To investigate the origin and transport pathways of air masses and provide insight into the WRF-Chem representation of BC, the FLEXPART-WRF model is run in backward mode. We identify four plumes originating from boreal fires on 17 July from Fig. 8 in the upper troposphere between 6 and $8 \mathrm{~km}$ and confirm them by in situ measurements from the aircraft. The center of those plumes has been found at 08:42 (BB1), 09:39 (BB2), 13:06 (BB3) and 14:10 (BB4) UTC. Their dominant biomass burning origin has been suggested by Fig. 9. We also consider two air masses predicted by the model to be influenced by flaring emissions, in the PBL $(0.7 \mathrm{~km})$ at 08:05 UTC (Fl1) and in the mid-troposphere $(3.7 \mathrm{~km})$ at $12: 35 \mathrm{UTC}(\mathrm{Fl} 2)$. Finally, two anthropogenic air masses have been selected in the mid-troposphere $(3.2-3.5 \mathrm{~km})$, in the proximity of Andøya at 08:30 (An1) and 14:45 UTC (An2). For each selected air mass, 10000 FLEXPART-WRF particles are released in a volume of $40 \mathrm{~km} \times 40 \mathrm{~km}$ (horizontally) and $1 \mathrm{~km}$ (vertically). Since transport timescales are typically lower than 10 days, each simulation is run backwards for 10 days to track the origin of air masses reported in Fig. 8.

Figure 10 shows the $0-20 \mathrm{~km}$ column of FLEXPARTWRF PES integrated for 10 days for the first fire plume (released at 08:42 UTC on 17 July), together with the altitude and $\mathrm{BC}$ concentration retrieved from the model and interpolated along each of the 10000 trajectories. A vertical cross section of $\mathrm{BC}$ interpolated along the plume centroid location is also shown. We note that the results are very similar for the four backward simulations in biomass burning plumes (not shown). Figure 10 highlights a cross-polar transport of biomass burning emissions from Siberian fires into the Arctic, which reach the Svalbard archipelago thanks to a pronounced northerly flow. These plumes have been probed in detail by the aircraft on the two flights on 17 July. During the ACCESS campaign in July 2012, this cross-polar transport of biomass burning pollution was caused by Arctic low-pressure systems, regular phenomena of the summertime Arctic circulation (Orsolini and Sorteberg, 2009). WRF-Chem meteorological analyses suggest that these Arctic transport events in the upper troposphere are due to WCBs linked to two wave cyclones over extreme northern Russia and eastern Siberia. The first one was present at $72^{\circ} \mathrm{N}, 80^{\circ} \mathrm{E}$ between 11 and 12 July and reached $970 \mathrm{hPa}$. The second cyclone, responsible of the plume curl over the North Pole (Fig. 10), moved northward and extended from $80^{\circ} \mathrm{N}, 140^{\circ} \mathrm{E}$ to $88^{\circ} \mathrm{N}, 180^{\circ} \mathrm{E}$, progressively deepening to reach a minimum surface pressure of $975 \mathrm{hPa}$.

Two large plumes enriched in $\mathrm{CO}$ and $\mathrm{BC}$ form over the south of the Krasnoyarsk region on 8-9 July and over Yakutia on 11-12 July and merge over eastern Siberia into a 


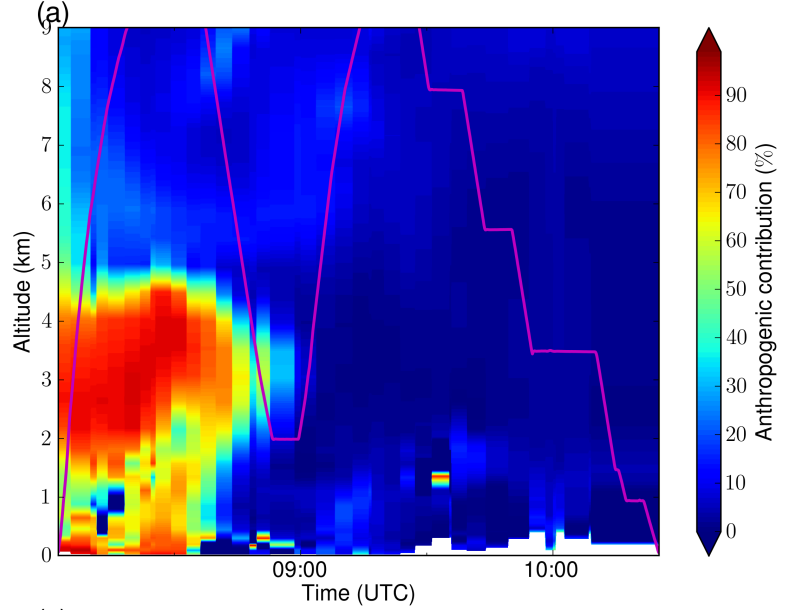

(c)

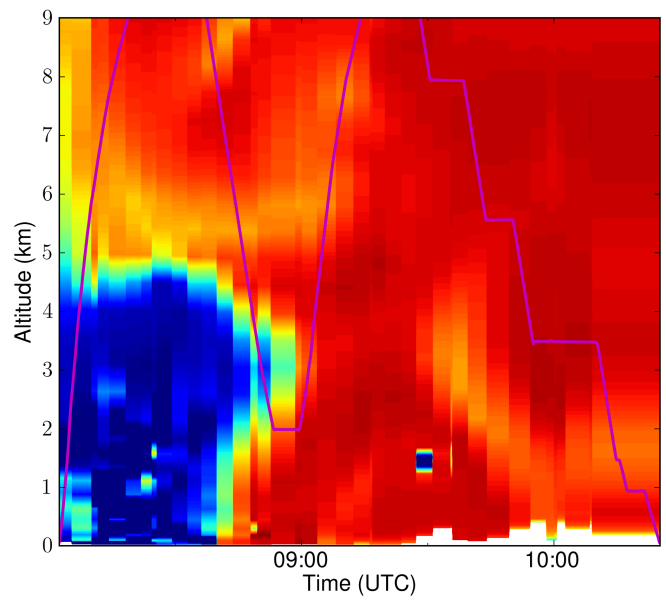

(e)

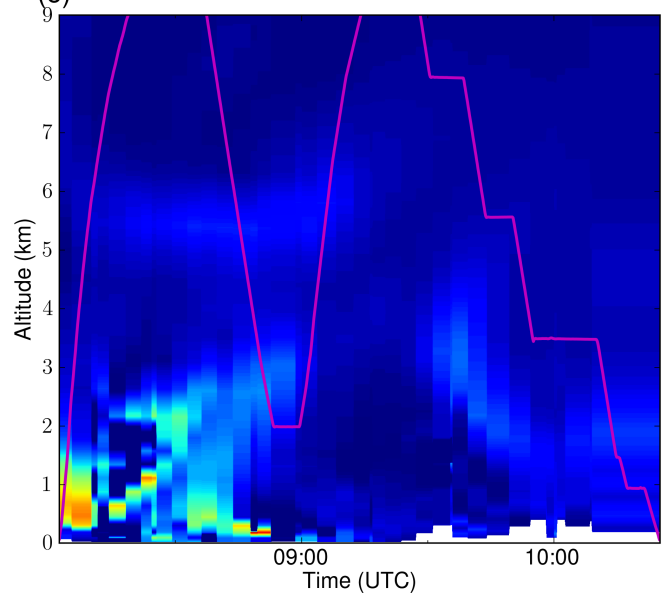

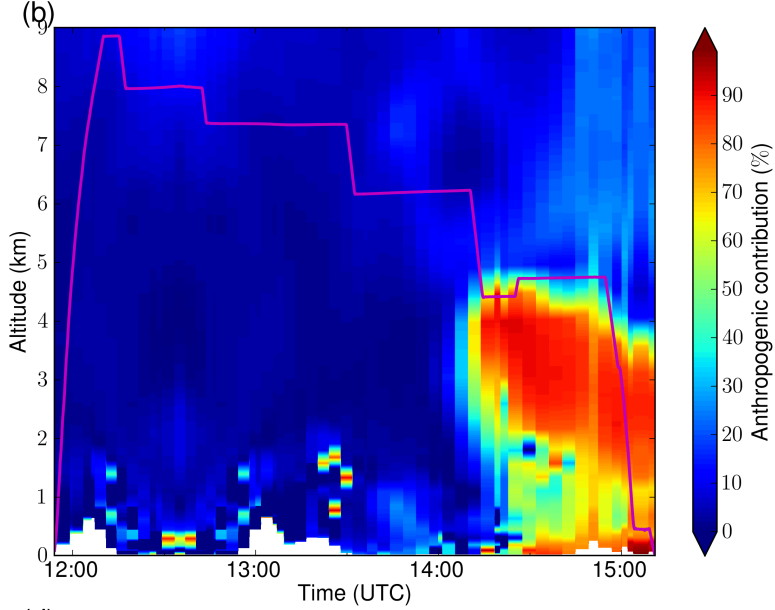

(d)
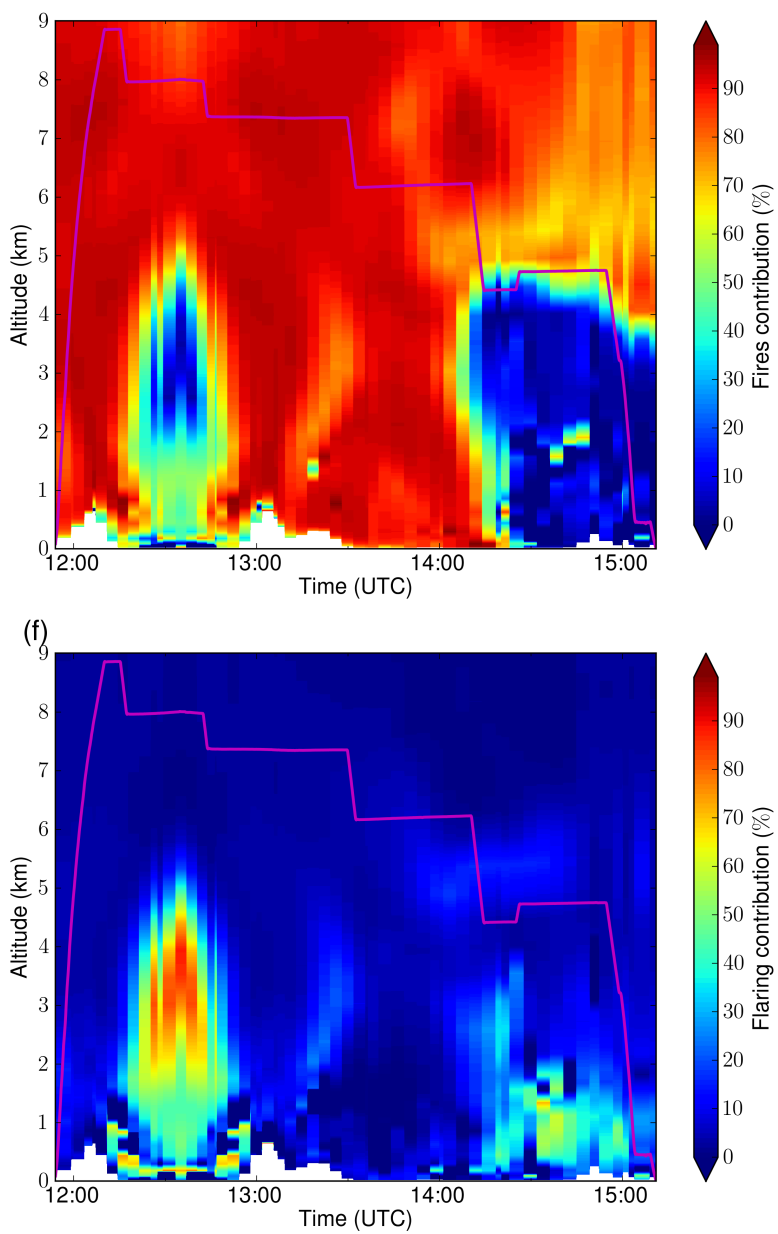

Figure 9. Time-altitude cross sections of the relative contributions (\%) of BC concentrations due to (a, b) anthropogenic, (c, d) biomass burning and (e, f) flaring emissions along flight tracks 17a (in panels $\mathbf{a}, \mathbf{c}$ and $\mathbf{e}$ ) and $17 \mathrm{~b}$ (in panels $\mathbf{b}, \mathbf{d}$ and $\mathbf{f}$ ). The altitude of the two flights is indicated in magenta in each panel.

large plume advected to higher latitudes. When the first lowpressure system forms at the surface, the plume intrudes into the Arctic atmosphere, where it elongates and becomes narrower (12 July). The second low-pressure system forms at $80^{\circ} \mathrm{N}, 140^{\circ} \mathrm{E}$, which facilitates the progression of the eastern part of the plume further north aloft. Due to the progression of the cyclone to the northeast $\left(88^{\circ} \mathrm{N}, 180^{\circ} \mathrm{E}\right)$, the plume elongates and moves almost over the North Pole (13 July). 
(a)

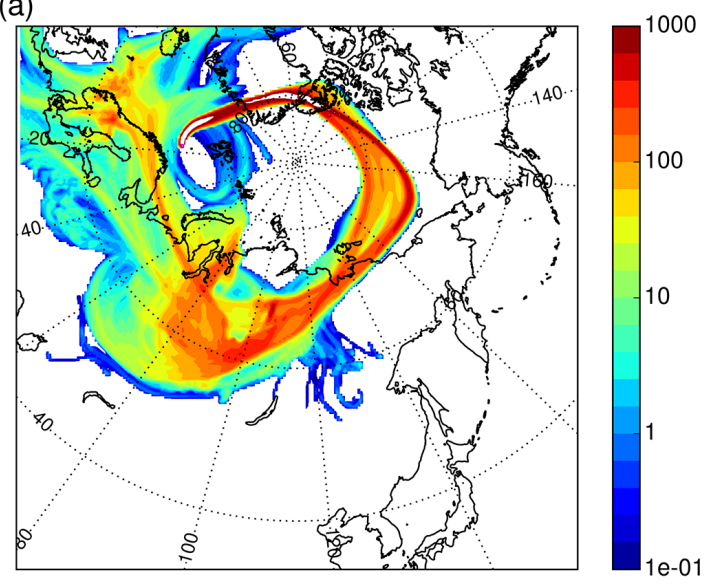

(c)

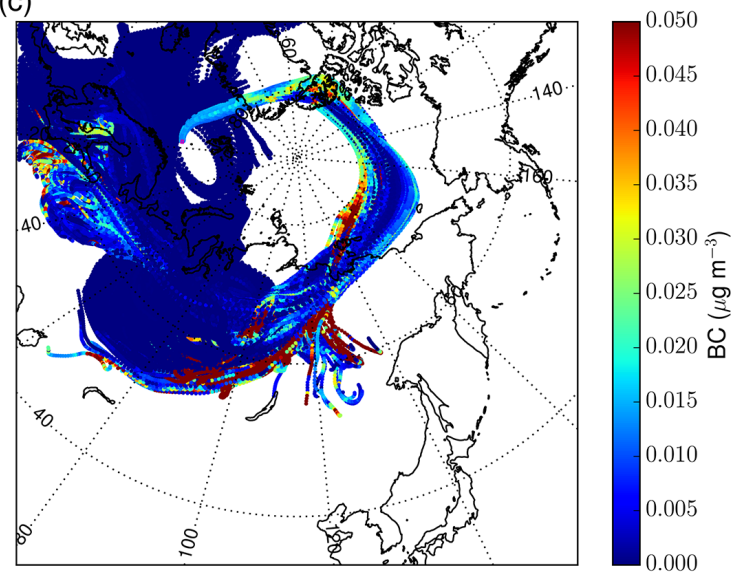

(b)

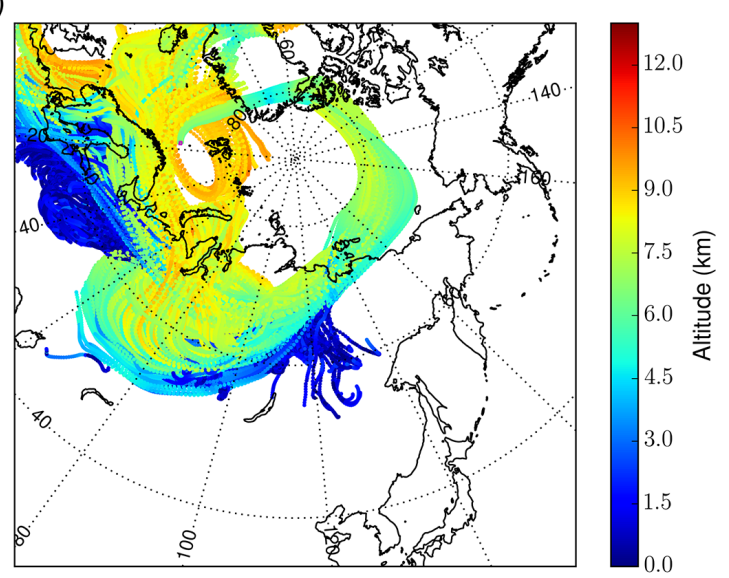

(d)

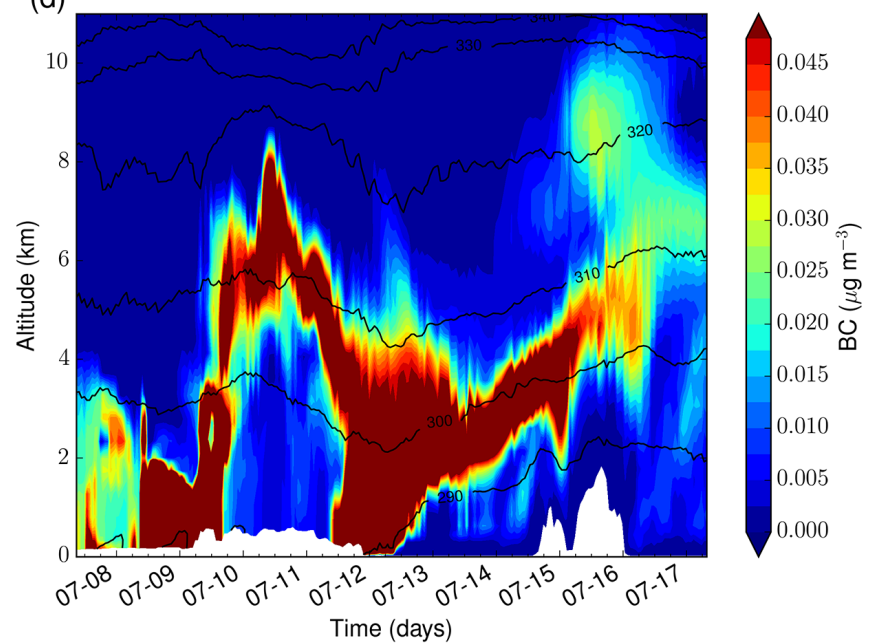

Figure 10. FLEXPART-WRF backward simulation from the biomass burning plume observed by the Falcon aircraft at $73.1^{\circ} \mathrm{N}, 18.2^{\circ} \mathrm{E}$ and $6.5 \mathrm{~km}$ between 08:37 and 08:47 UTC. (a) Column-integrated PES, (b) altitude and (c) BC mass concentration interpolated along the 10000 trajectories for 10 days prior to the release. In panel (d), the vertical cross section of BC interpolated along the plume centroid location is shown, together with the dry isentropes (black lines) between 290 and $340 \mathrm{~K}$.

Along the plume boundaries, some mixing processes with the surrounding air occur, partly eroding its outer parts and leading to a filamentary structure. The aging plume is split into two branches reaching northern Canada on 14 July and moving towards Svalbard. The relatively fine resolution of our simulations $(40 \mathrm{~km})$ can resolve the increased filamentation of the pollution plumes, an advantage over most global models with coarser grids (Sodemann et al., 2011; Ma et al., 2014). The concentrations of $\mathrm{CO}$ and $\mathrm{BC}$ interpolated along trajectories generally decrease with time due to mixing with the surrounding clean atmosphere and deposition processes along transport (Fig. 10), except on 14-15 July, when two plume branches of the same initial plume merge together.

Figure 9 also demonstrates a small contribution $(15 \%)$ of anthropogenic sources to the enhanced $\mathrm{CO}$ and $\mathrm{BC}$ detected by the Falcon observations. As suggested by Fig. 10, the an- thropogenic emissions that arrive near Norway may originate from fossil-fuel burning in northern China, where high levels of $\mathrm{BC}$ have been modeled 10 days before the flights on 17 July (Fig. 7). These emissions undergo a strong and efficient uplift from the PBL to the middle and upper troposphere within WCBs and therefore enter the Arctic at high altitudes. Those Asian anthropogenic air masses are characterized by high water vapor mixing ratios $\left(14 \mathrm{~g} \mathrm{~kg}^{-1}\right)$ and $\mathrm{RH}$ values larger than $80 \%$, facilitating their uplift over cold, dense Arctic air masses. The fact that the contribution of fossil-fuel emissions is found to be weak over Scandinavia suggests that significant deposition of aerosols occurs during transport. Wet removal is due to cloud formation and a high amount of precipitation during uplift, mostly convective rain (Fig. 5). It is also characterized by an enhancement of po- 
tential temperature from 300 to $315 \mathrm{~K}$ caused by latent heat release from water vapor condensation.

According to Serreze and Barrett (2008) and Orsolini and Sorteberg (2009), such pollution transport events characterized by the presence of low-pressure systems in summer could be a common and effective transport mechanism to the Arctic atmosphere for Siberian forest fires and Asian industrial emissions. Such transport pathways reaching the Arctic have been observed by Sodemann et al. (2011) and Roiger et al. (2011) during July 2008. In our study, the low-pressure systems are more intense (surface pressures ranging from 970 to $975 \mathrm{hPa}$ ), suggesting an effective mechanism for intrusion of pollutants into northern Norway.

The pollution plumes exported from the flaring emission sources follow different pathways as a function of their altitude. The plume reaching Scandinavia in the PBL is exported above the West Siberian Plain, where large values of the poleward eddy heat flux are predicted (Fig. 7), and passes over the Barents Sea before progressing poleward at low level. However, another plume emitted from the flares in western Siberia is transported eastward along the Siberian coast, moves to the north over Yakutia, curls over the North Pole before reaching Svalbard in the mid-troposphere. Finally, the two anthropogenic plumes identified in the mid-troposphere close to Andøya island are exported from Europe in about 6 days.

\section{Deposition during transport}

\subsection{Contribution of deposition processes}

To understand the contributions of the different deposition processes (dry deposition, wet removal in grid-resolved clouds and in parameterized convective clouds) on the mass of $\mathrm{BC}$ transported to the region of the flights, we use the normalized differences between the NoX simulations and the BASE run, where NoX represents the NoDry, NoWet or NoWetCu simulations: $100 \times\left(\frac{\text { NoX-BASE }}{\text { NoX }}\right)$. Model results from those four runs are interpolated in time and latitude and longitude at the position of the Falcon during the two flights on 17 July. Figure 11 shows the time-altitude cross sections of the relative contributions of the different deposition processes.

The dry deposition is only significant (more than $50 \%$ ) in the lowest layers, and close to the Norwegian coast. Due to the fact that BC particles predominantly occupy the Aitken and accumulation mode ( $90 \%$ of BC particles have a diameter lower than $2.5 \mu \mathrm{m}$ in our simulation), the impact of the sedimentation process is very weak. Dry deposition of BCcontaining particles therefore arises from the aerodynamic transport down through the atmospheric layer to a very thin layer of stagnant air just adjacent to the surface (by turbulent diffusion) and from the Brownian transport across this quasilaminar sublayer to the surface itself. As a consequence, the role of dry deposition is limited to the lower troposphere
(PBL). More important are the impacts of wet deposition processes in grid-scale and subgrid parameterized clouds. Gridscale wet removal has the largest effect $(80 \%$ BC removal) in the mid-troposphere, where European anthropogenic influence is also large (Fig. 9). Altitudes influenced by biomass burning plumes (Fig. 9) experience similar BC removal rates, 40-60\%, from both grid-scale and subgrid-scale clouds. In the areas where the biomass burning plumes were more intense, as identified in Sect. 4.2, the impact of the deposition processes is generally smaller, almost negligible for dry deposition, about $30 \%$ for wet removal in grid-scale clouds and $10 \%$ in convective clouds. The fact that the maximum in BC concentrations corresponds to zones less affected by deposition processes illustrates the heterogeneous vertical cross sections of BC (Fig. 8). The vertical profile of BC (Fig. 3) would have therefore peaked more intensively in the midand upper troposphere if wet removal had been less efficient. Between 4 and $6 \mathrm{~km}$, the $\mathrm{BC}$ mixing ratio would have been multiplied by a factor of 3 without wet removal in subgrid convective clouds, or by a factor of 4 without wet removal in grid-scale clouds.

$\mathrm{BC}$ particles coated with non-refractory and water-soluble secondary compounds can be $\mathrm{CCN}$ (cloud condensation nuclei) active in liquid clouds. BC-containing particles can also act as IN (ice nuclei). In the MOSAIC aerosol module used in WRF-Chem, aerosol components are assumed to undergo a instantaneous internal mixing in each size bin. Petters et al. (2009) showed that internally mixed BC particles can be more hygroscopic and easily removed by wet scavenging compared to externally mixed BC. This should not have a large effect on our results as BC particles sampled by the Falcon have principally been transported in biomass burning plumes from Siberia (Sect. 4.4). Kondo et al. (2011) and Sahu et al. (2012) observed that BC in biomass burning plumes is often more internally mixed than in fossil-fuel emissions, frequently shows very thick coatings (Dahlkötter et al., 2014) and is thought to occur in the first few hours after emission (Abel et al., 2003; Akagi et al., 2012).

During the long-range transport of plumes towards the Arctic region, the WCBs observed in this study loft aerosols from the PBL to the free troposphere, or rapidly inject them into the upper troposphere, in the warm section of midlatitude cyclones. Clouds form and a significant portion of particles becoming efficient $\mathrm{CCN}$ is scavenged by cloud droplets or rain drops and potentially removed from the atmosphere via wet deposition in those vertical transport pathways. A fraction of aerosols may survive this deposition associated with the cyclones, reach higher altitudes and travel to polar latitudes. However, a small portion of the remaining interstitial $\mathrm{BC}$ particles can be removed through impaction scavenging by collection of cloud or rain droplets. This process is said to be more effective for BC removal, both in mixed-phase (Twohy et al., 2010) and in ice clouds (Baumgardner et al., 2008; Stith et al., 2011). This is particularly important in this study as Fig. 6 indicated that ice, super- 

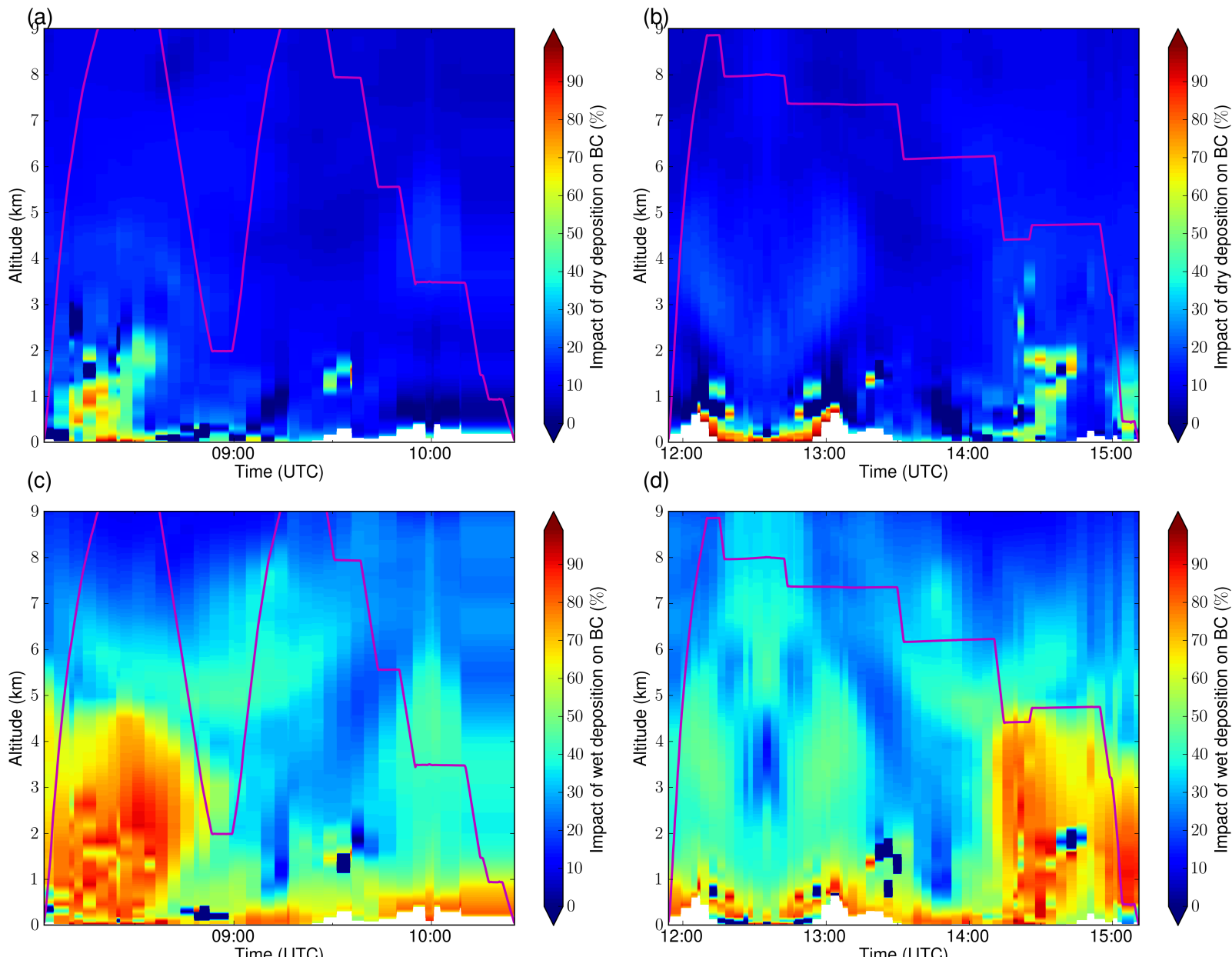

(d)
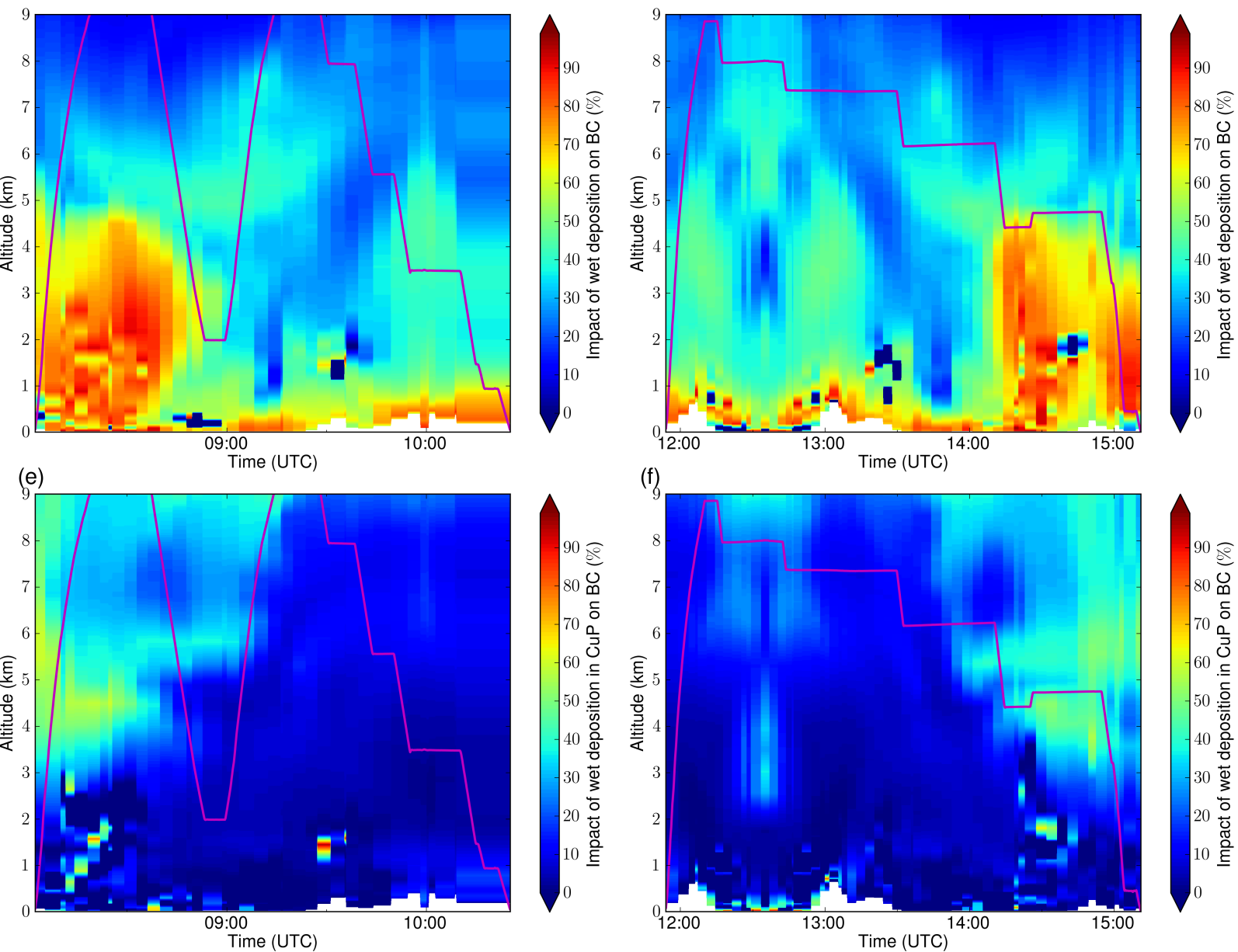

Figure 11. Time-altitude cross sections of the relative contributions (\%) of $(\mathbf{a}, \mathbf{b})$ dry deposition, $(\mathbf{c}, \mathbf{d})$ wet deposition in grid-resolved clouds and $(\mathbf{e}, \mathbf{f})$ wet deposition in parameterized cumulus clouds to the BC mass mixing ratio along flight tracks $17 \mathrm{a}$ (in panels $\mathbf{a}, \mathbf{c}$ and $\mathbf{e}$ ) and $17 \mathrm{~b}$ (in panels $\mathbf{b}, \mathbf{d}$ and $\mathbf{f}$ ). The altitude of the two flights is indicated in magenta in each panel.

cooled and mixed-phase clouds are predominant in the midtroposphere during the ACCESS period.

\subsection{Impact of deposition}

Figure 12 shows the accumulated deposition of $\mathrm{BC}$ between 7 and 21 July, which is the period during which aerosols 

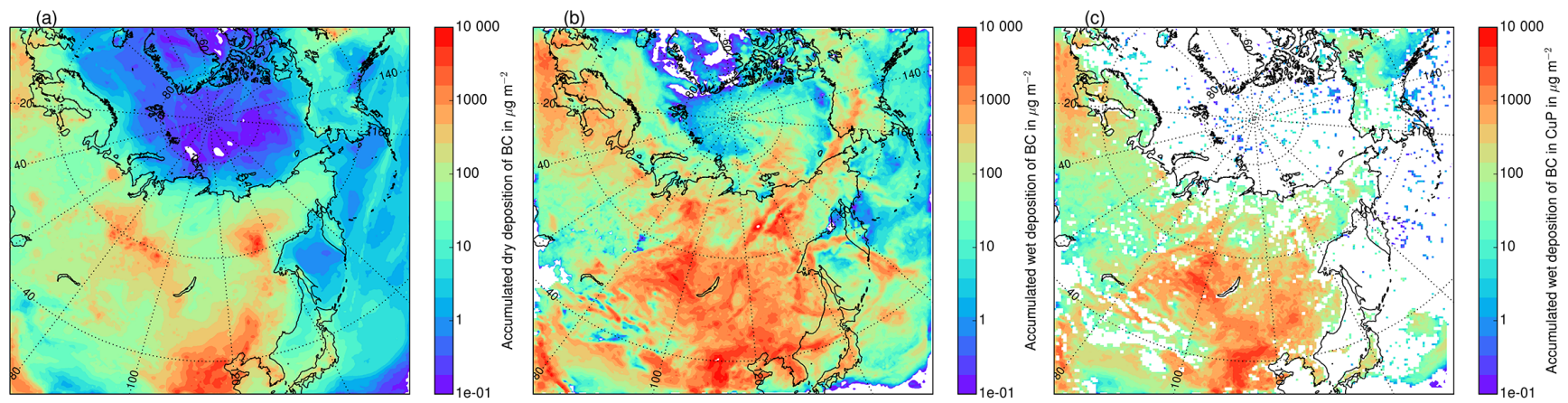

Figure 12. Accumulated deposition of BC due the (a) dry deposition, (b) wet removal in all clouds (grid-resolved and cumuli) and (c) wet removal in parameterized cumulus clouds between 7 and 21 July. Note the logarithmic color scale.

were transported from mid-latitudes to the Scandinavia. The three types of deposition processes are studied here: dry deposition, wet removal by large-scale precipitation (first-order rainout and washout) and scavenging in wet convective updrafts. The deposition of $\mathrm{BC}$ is clearly dominated by wet removal from the middle to high latitudes. The impact of dry deposition can only been observed near emission sources: the spatial distribution of accumulated $\mathrm{BC}$ by dry deposition is co-located with the divergence regions of the horizontal $\mathrm{BC}$ flux in the PBL (Fig.7), which may therefore correspond to the spatial distribution of $\mathrm{BC}$ emissions. Sedimentation and turbulent mix-out are indeed the major sink of coarse particles containing BC near emission sources. The dry deposition flux of BC particles from the troposphere to the surface is moreover almost proportional to the local $\mathrm{BC}$ mass mixing ratio near the surface. In large-scale clouds, BC particles are removed through the nucleation scavenging mechanism, or through wet deposition processes (in-cloud scavenging is referred to as rainout, and below-cloud scavenging is referred to as washout), where particles are collected by falling hydrometeors (in stratiform precipitation) through Brownian motion, electrostatic forces, collision or impaction (Seinfeld and Pandis, 2006). Interstitial and cloud-borne BCcontaining particles can finally be removed in the strong updraft core of deep convective clouds parameterized in KFCuP (Kain-Fritsch-Cumulus Parameterization).

The horizontal distribution of $\mathrm{BC}$ wet removal results from a combined effect of the precipitation amounts (Fig. 5) and the upward BC flux (Fig. 7). During the vertical transport of plumes containing carbonaceous aerosols, the wet deposition is indeed directly linked to the distribution of precipitation. The spatial distribution of $\mathrm{BC}$ scavenged by wet deposition in parameterized cumulus clouds matches that of convective precipitation well (Fig. 5). Aerosol wet removal from predicted deep and shallow convective clouds is, however, lower than the removal from grid-scale clouds. This is the case even where the cumulus scheme predicts greater amounts of precipitation than the microphysical scheme (Fig. 5). This KFCuP scheme triggers almost everywhere in the mid- latitudes, but not so much over the oceans and in the Arctic or sub-Arctic (beyond $60^{\circ} \mathrm{N}$ ), where it is mostly dominated by the formation of low-level stratocumulus cloud decks in the boundary layer and lower troposphere, producing frequent drizzle (Browse et al., 2012). We have to note that the KFCuP mechanism actually lacks below-cloud wet scavenging and scavenging by snow and ice. Adding the below-cloud scavenging by the convective precipitation would nevertheless have only a minor impact on the $\mathrm{BC}$ concentrations: assuming that nearly all the BC was in the $80-470 \mathrm{~nm}$ diameter range, the below-cloud removal efficiencies are indeed very small for large rain drops below cumuli. Some of the enhanced wet removal in cumuli must be compensated for by the enhanced vertical transport of aerosols from the PBL into the free troposphere during deep convection (Berg et al., 2015). It is also important to bear in mind that the cumulus cloud fraction within the model grid box (here $40 \mathrm{~km}$ ) can be quite small, so that the wet removal occurs over a relatively small area and does not have a large impact on the total aerosol loading within the model grid box. While validating the KFCuP cumulus scheme, Berg et al. (2015) highlighted a reduction in low-altitude aerosol associated with the venting of aerosol from the PBL as well as changes in the vertical structure associated with the cumulus induced subsidence, but little change in the average aerosol aloft. This may also be consistent with the small amount of secondary activation in the simulations.

During the summer of 2012, the wet removal is the dominant process at all latitudes, which illustrates that a substantial fraction of $\mathrm{BC}$ mass concentrations is removed in the regions south of $70^{\circ} \mathrm{N}$ before reaching the Arctic.

The influence of wet removal of BC scavenging is also predicted in the high latitudes in summer, underlining the role of drizzle from low-level clouds and fogs. The combination of low-level scavenging in the Arctic region and transport decrease from mid-latitudes is the cause of the low summertime $\mathrm{BC}$ concentrations. We note the fact that the WRF-Chem performs worse at $100 \mathrm{~km}$ in reproducing the mean $\mathrm{BC}$ profile observed by the Falcon, particularly in the mid-troposphere 
(Fig. 3) suggests that the coarse resolution and the increased role of convective clouds result in less efficient $\mathrm{BC}$ removal during transport. This is due to the presence of weakly precipitating shallow clouds at high latitudes, which do not scavenge aerosols adequately.

\subsection{Transport efficiency of BC particles}

\subsubsection{Role of accumulated precipitation and condensed water along FLEXPART-WRF trajectories}

To investigate the transport efficiency of $\mathrm{BC}$ particles and evaluate the effects of the wet removal of $\mathrm{BC}$ from the atmosphere by precipitation during transport, we use the NoWetAll simulation, which does not consider aerosol wet deposition both in grid-scale and in parameterized convective clouds. We define the transport efficiency of BC as

$\mathrm{TE}_{\mathrm{BC}}=\frac{[\mathrm{BC}]_{\mathrm{BASE}}}{[\mathrm{BC}]_{\text {NoWetAll }}}$.

Similar quantities have been used in previous studies (e.g., Koike et al., 2003; Matsui et al., 2011; Oshima et al., 2012), but the denominator was often chosen as the observed $\mathrm{BC}$ to- $\mathrm{CO}$ ratios for the source regions rather than its value extracted from a simulation where wet removal has been turned off, as in Oshima et al. (2013).

Following the methodology of Oshima et al. (2012), who investigated the role of wet removal of $\mathrm{BC}$ in Asian outflow towards the Pacific Ocean, we estimate the accumulated precipitation along trajectory (APT) and use it as a proxy for wet deposition. APT represents the amount of precipitation that an air parcel had experienced during transport. For every sampled air parcel by the Falcon and identified as a plume on 17 July in Sect. 4.4, the $\mathrm{TE}_{\mathrm{BC}}$ and APT values are computed along each of the 10000 FLEXPART-WRF trajectories released at the time and location of the plume. Specifically, the APT is derived by integrating the WRF-Chem precipitation amounts from the BASE run along each Lagrangian 10-day backward trajectory of the corresponding uplifted air parcel. For the plume originating from Russian flaring sources (rapidly transported at a low altitude; Sect. 4.4), the trajectory runs backwards for 6 days. At hourly intervals, the rain, ice, snow and graupel precipitation rates (including values in cumuli) are interpolated at the closest WRFChem grid box of the FLEXPART-WRF trajectory, summed and then integrated in time. This method is preferred to the one based on the WRF-Chem surface precipitation amounts that would not take into account the relative vertical distribution of precipitation occurrence and air parcels. Similarly, we also extract the accumulated condensed water along trajectory (ACWT) to account for the fact that BC particles are also removed from the plumes during activation. This process, called the nucleation scavenging mechanism, refers to the transfer of particles from interstitial aerosol to cloudborne aerosol. The ACWT is calculated using the method applied for APT but based on the mixing ratios of cloud liquid water, ice, snow, rain and graupel contents both in gridscale and convective parameterized clouds. The mixing ratios are summed and integrated vertically in each model grid box crossed by the trajectory and finally along this trajectory. The nucleation scavenging mechanism can be considered as aerosol removal from the plume when cloud droplets containing aerosols reach the sizes of precipitating rain drops in other cells, e.g., those above or below the grid box crossed by the trajectory. $\mathrm{TE}_{\mathrm{BC}}, \mathrm{APT}$ and $\mathrm{ACWT}$ values extracted along each of the trajectories are then averaged to give a mean trajectory corresponding to an uplifted air parcel.

\subsubsection{Results along trajectories}

In Sect. 4.4, eight distinct plumes have been identified: four plumes originating from boreal fire sources in Russia (associated with a small influence of anthropogenic Asian air masses; Fig 9), two plumes from flaring activities in northern Russia and two anthropogenic plumes from Europe. Figure 13 shows the dependence of $\mathrm{TE}_{\mathrm{BC}}$ for these eight plumes on the APT and ACWT as a function of the FLEXPARTWRF transport time. TE $\mathrm{BC}_{\mathrm{BC}}$ systematically decreases with increasing APT or ACWT, reflecting the crucial role of precipitation and nucleation scavenging in removing particles containing $\mathrm{BC}$ from advected plumes along transport, and thereby in controlling the amount of $\mathrm{BC}$ reaching the Arctic. An exception occurs on 14-15 July, when $\mathrm{TE}_{\mathrm{BC}}$ slightly increases in some plumes, because two branches of the same initial plume merge over northern Canada (Sect. 4.4). $\mathrm{TE}_{\mathrm{BC}}$ decline is not linear with APT or ACWT (logarithmic scale in Fig. 13) but starts to significantly decrease 6-7 days (144$168 \mathrm{~h}$ ) before reaching Scandinavia, corresponding to APT values of $0.2-0.4 \mathrm{~mm}$ and ACWT between 200 and $400 \mathrm{~mm}$.

When reaching Scandinavia (retroplume age very young), plumes present various values of $\mathrm{TE}_{\mathrm{BC}}$ as a function of their origins. $\mathrm{TE}_{\mathrm{BC}}$ is the greatest for Siberian biomass-burningimpacted air masses. As shown in Fig. 9, $85 \%$ of the BC sampled by the aircraft in such plumes originated from boreal fires and $15 \%$ from Asian anthropogenic masses. In such plumes, the $\mathrm{TE}_{\mathrm{BC}}$ was as high as $56-68 \%$ and was caused by low APT and ACWT values (1 mm and 300-1000 mm, respectively). In contrast, $\mathrm{TE}_{\mathrm{BC}}$ was low (21-28\%) and APT and ACWT amounts were high for European anthropogenic air parcels (5-10 and 2000-3000 mm, respectively). Air parcels influenced by flaring emissions exhibit very different behavior as a function of their altitude: moderate $\mathrm{TE}_{\mathrm{BC}}$ values $(50 \%)$ were calculated in plumes reaching the middle Arctic troposphere $(3.7 \mathrm{~km})$, whereas $\mathrm{TE}_{\mathrm{BC}}$ decreased to $20 \%$ in plumes transported in the PBL. The fact that the relation between $\mathrm{TE}_{\mathrm{BC}}$ and $\mathrm{ACWT}$ is different from the one between $\mathrm{TE}_{\mathrm{BC}}$ and APT, especially in flaring plumes, indicates a role of cloud liquid water and ice crystals in clouds to remove $\mathrm{BC}$ during transport. This is caused by the nucleation scavenging mechanism. ACWT appears to be a better proxy 

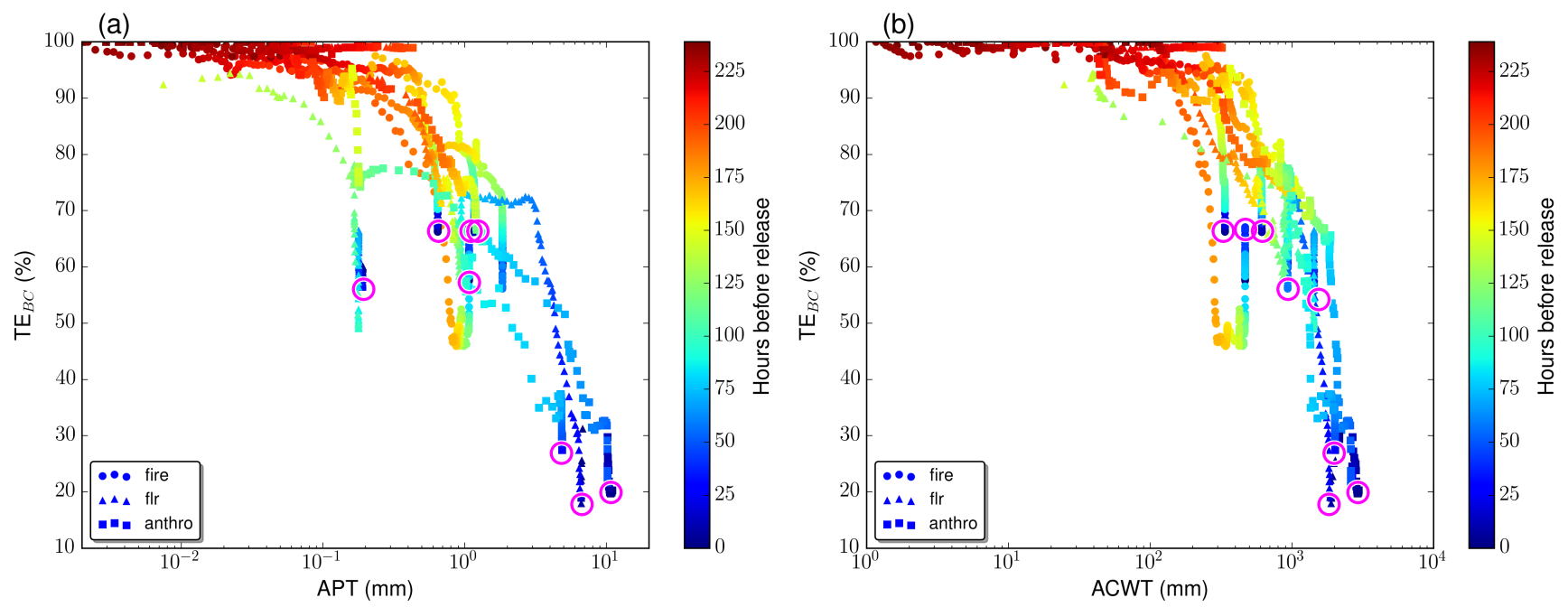

Figure 13. Transport efficiency of $\mathrm{BC}\left(\mathrm{TE}_{\mathrm{BC}}\right)$ for eight plumes identified from sampled air parcels by the Falcon (four boreal fire plumes, two plumes from flaring activities in northern Russia and two anthropogenic plumes from Europe) as a function of (a) the accumulated precipitation along trajectory (APT) and (b) the accumulated condensed water along trajectory (ACWT). The points are colored by the time (in hours) before the release of the trajectories in FLEXPART-WRF. Magenta circles emphasize the starting points (release time $=0$ ) of the eight air masses discussed in Sect. 4.4.

for characterizing the efficiency of aerosol removal in such air parcels, since the values are of the same order of magnitude in both flaring-impacted air masses (1000-2000 mm), while APT varies from $0.2 \mathrm{~mm}$ (in mid-tropospheric plumes) to $8 \mathrm{~mm}$ (in PBL plumes).

The magnitude of the differences in $\mathrm{TE}_{\mathrm{BC}}$ values obtained during the same period due to various origins is particularly noticeable. European anthropogenic air parcels and flaring emissions are generally transported at lower altitudes than biomass burning air masses, according to Fig. 8. They encountered more non-convective precipitation caused by frequent drizzle in low-level stratocumulus clouds, scavenging aerosols during transport. In contrast, Russian and to a lesser extent Asian air masses have exported BC more efficiently towards the Arctic. Most air parcels from those sources have experienced transport in WCBs, removing part of the $\mathrm{BC}$ loadings. However, the transport of aerosols has been facilitated thanks to the injection of fire plumes at high altitudes and to the fact that biomass burning sources in Siberia are located far north in summer $\left(45-65^{\circ} \mathrm{N}\right)$. These results are in agreement with previous studies from Matsui et al. (2011) and Sharma et al. (2013). They underlined a significant inhibition of emissions from eastern Asia (90\%) compared to biomass burning sources in Russia on the total Arctic BC, because of larger precipitation rates and stronger scavenging.

\subsubsection{Zonal mean of transport efficiency}

The vertical distributions of the mean $\mathrm{BC}$ mass concentrations zonally averaged during the ACCESS period in the BASE run and the corresponding mean $\mathrm{TE}_{\mathrm{BC}}$ values due to grid-scale clouds and all clouds are shown in Fig. 14. The
WRF-Chem domain (Fig. 1) is appropriate for this calculation because all sources influencing the Arctic $\mathrm{BC}$ during the ACCESS period are in this domain: the sum of anthropogenic, flaring and fire contributions was found to be larger than $98 \%$ (Fig. 9). The BC mass concentrations are greatest below the altitude of $4 \mathrm{~km}$ on the mid-latitude region $\left(40-66^{\circ} \mathrm{N}\right)$ with values larger than $50 \mathrm{ng} \mathrm{m}^{-3}$. The highest concentrations $\left(>100 \mathrm{ng} \mathrm{m}^{-3}\right)$ are found close to emission sources and they continuously decrease with height. A high contrast is observed between the mid-latitudes and the Arctic. In the mid-troposphere $(3-6 \mathrm{~km})$, the contrast is less pronounced as moderate BC concentrations are spread over a wide latitude range. As a consequence, above $80^{\circ} \mathrm{N}$, lowest $\mathrm{BC}$ concentrations are found at the surface, and the maximum is detected between 2 and $4 \mathrm{~km}\left(15 \mathrm{ng} \mathrm{m}^{-3}\right)$.

In contrast, $\mathrm{TE}_{\mathrm{BC}}$ due to only grid-scale precipitation exhibits a very distinct dependency on latitude: above $70^{\circ} \mathrm{N}$, $\mathrm{TE}_{\mathrm{BC}}$ decreases from 70-85 to 44-69\%. This sharp meridional gradient is due to the fact that $\mathrm{TE}_{\mathrm{BC}}$ is indeed smaller for air experiencing wet removal over Asia or Siberia and that is subsequently transported to the outflow regions (high latitudes). This explains the contrast between the $\mathrm{BC}$ concentrations in the mid-latitudes and in the Arctic region. Within the Arctic, the maximum of $\mathrm{TE}_{\mathrm{BC}}(\simeq 69 \%)$ is found at higher altitudes $(4$ and $6 \mathrm{~km}$ ) than the maximum in $\mathrm{BC}$ concentrations. This provides evidence that the transport in WCBs partly, but not completely, removes carbonaceous aerosols by wet deposition. The low BC concentrations in the lowest polar layers are correlated with a weak transport efficiency $(\simeq 45 \%)$. This is due to frequent drizzle produced by the formation of low-level stratocumulus clouds in the Arctic PBL and lower 

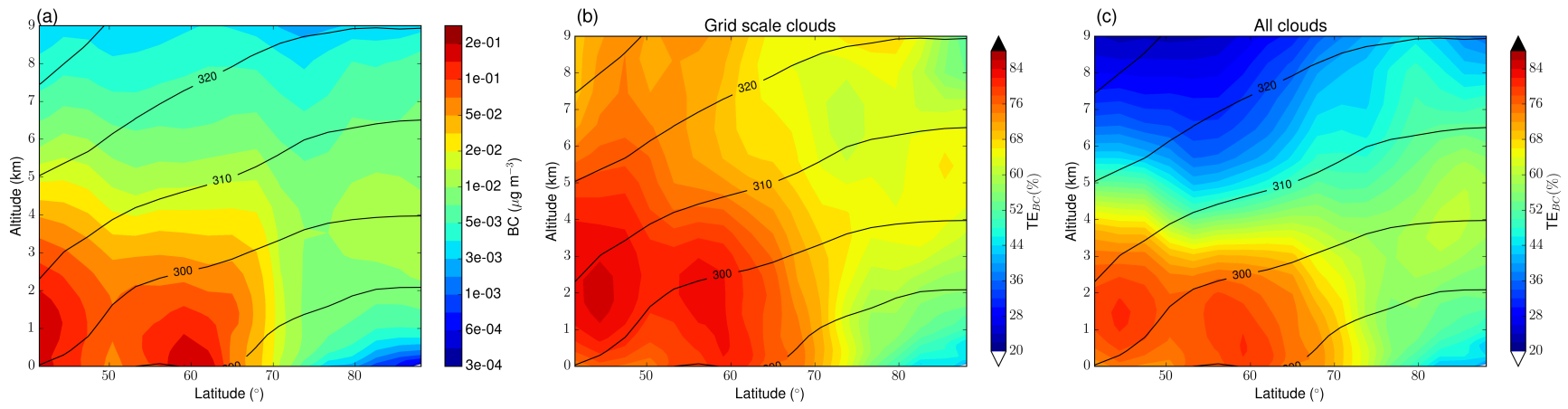

Figure 14. Latitude-altitude cross sections of (a) the BC mass concentrations, and the corresponding TE $\mathrm{BC}_{\mathrm{BC}}$ values due to (b) grid-scale clouds and (c) all clouds, averaged zonally and temporally over the ACCESS campaign period in the BASE run. On each panel, black solid lines represent the dry isentropes between 290 and $330 \mathrm{~K}$.

troposphere, together with a slower transport in the lowest altitudes. It is also interesting to note that in the mid-latitude regions, higher $\mathrm{TE}_{\mathrm{BC}}$ are decoupled from the surface, reflecting the strong uplift of Siberian fire emissions above boreal forest. The associated strong ascent generally occurs at subgrid scale $(<40 \mathrm{~km})$, which explains the inability of wet removal in large-scale precipitation to clean the atmosphere above sources.

$\mathrm{TE}_{\mathrm{BC}}$ due to wet removal in all clouds exhibits a totally different pattern. $\mathrm{TE}_{\mathrm{BC}}$ values are correlated more closely with $\mathrm{BC}$ mass concentrations, suggesting that wet removal in subgrid parameterized clouds (cumuli) is also fundamental to understand the vertical distribution of BC mass. It also suggests that cumuli in the mid-latitudes removed more of the low-level aerosol by scavenging or washout than by uplifting it. Aerosol removal in cumulus clouds is responsible of the vertical gradient of $\mathrm{TE}_{\mathrm{BC}}$, especially in the mid-latitudes. Two noticeable differences between the zonal cross sections of $\mathrm{BC}$ and $\mathrm{TE}_{\mathrm{BC}}$ are observed. First, in mid-latitudes (40$\left.70^{\circ} \mathrm{N}\right), \mathrm{TE}_{\mathrm{BC}}$ is low above $6 \mathrm{~km}\left(\mathrm{TE}_{\mathrm{BC}}<20 \%\right)$, whereas $\mathrm{BC}$ concentrations reach moderate values in this altitude range: this reflects the efficient $\mathrm{BC}$ wet removal due to convection and precipitation during the rapid ascent over the source regions. The $\mathrm{BC}$ mass concentrations observed above $6 \mathrm{~km}$ mainly arise from the boundaries. Second, in the Arctic, the maximum of $\mathrm{TE}_{\mathrm{BC}}$ is located between 3.5 and $5.5 \mathrm{~km}$ (as high as 64\%): it illustrates the fact that the transport of Siberian fire plumes closely followed isotropes, as also noticed by Matsui et al. (2011). Wet removal of aerosols tightly modulates long-range transport from Asia and Siberia to the Arctic, with a marked zonal component and transport at higher altitudes. It is important to note that the transport efficiency is probably slightly overestimated in our study because the model slightly overpredicts $\mathrm{BC}$ mixing ratios in the mid-troposphere (Fig. 3).

The Siberian plume has been sampled by the Falcon in the upper troposphere $(6-8 \mathrm{~km})$. In Fig. 14 , we find that $\mathrm{TE}_{\mathrm{BC}}$ is about $60 \%$, which is in agreement with the value found by along trajectories (Fig. 13). The altitude dependence of BC in the ACCESS aircraft measurements (Fig. 3 and Fig. 8) is consistent with the zonally and temporally averaged $T_{B C}$ distribution simulated in the BASE simulation during the ACCESS campaign period. This suggests that the general features of wet removal of $\mathrm{BC}$ transported in plumes from Siberia and Asia during summer 2012 were well captured in the ACCESS aircraft measurements. We finally note that the $\mathrm{TE}_{\mathrm{BC}}$ values in this study are much larger than the ones reported by Matsui et al. (2011). That discrepancy is partially due to the different year (2008 vs. 2012) with different emissions and precipitation patterns (APT values much lower in our study). In addition, the definition of $\mathrm{TE}_{\mathrm{BC}}$, used by Matsui et al. (2011), is the transport efficiency of BC uplifted air masses sampled by the aircraft relative to their corresponding sources. In our study, $\mathrm{TE}_{\mathrm{BC}}$ represents the transport efficiency of BC due only to wet removal in grid-scale and subgrid parameterized convective clouds. If a plume emitted from a specific source diverges before reaching the receptor area, the transport efficiency calculated by the method of Matsui et al. (2011) will decrease. In our modeling study, the transport efficiencies are only influenced by precipitation and are therefore higher. They illustrate the role of aerosol removal during transport rather than the contribution of the transport itself.

\section{Summary and conclusions}

During the ACCESS campaign in summer 2012, extensive boreal forest fires associated with temperatures record in both western and eastern Siberia strongly impacted the atmospheric composition of the Arctic atmosphere. The Falcon aircraft regularly sampled transported pollution. During two dedicated flights on 17 July, it measured plumes in the middle and upper troposphere that were representative of cross-polar transport from Siberia and Asia towards Scandinavia and the Svalbard archipelago. Specifically, enhanced CO concentrations and $\mathrm{BC}$ mixing ratios up to $200 \mathrm{ppbv}$ and $25 \mathrm{ng} \mathrm{kg}^{-1}$ 
are reported between 6 and $8 \mathrm{~km}$ altitude, reflecting the influence of pollution transported from remote sources. The WRF-Chem model run at a horizontal resolution of $40 \mathrm{~km}$ on a polar stereographic projection shows good skill in capturing the variability observed in the vertical distribution of chemical profiles, with NMB of 1.5 and $27.3 \%$ for $\mathrm{CO}$ and $\mathrm{BC}$ respectively. $\mathrm{BC}$ increases in the middle and upper troposphere are mostly linked to biomass burning plumes transported from boreal sources ( $85 \%$ ), weakly influenced by anthropogenic sources in northern China (15\%).

Our results underline that a coarser horizontal resolution $(100 \mathrm{~km}$ instead of $40 \mathrm{~km})$ deteriorates the model performance, with a significant overestimation of $\mathrm{BC}$ levels in the mid-troposphere. This suggests that, at a coarser resolution, the model is unable to resolve the fine structure of plumes transported in altitude across the North Pole, illustrates the difficulty to represent the cloud and precipitation structures and scavenging processes at subgrid scale and points to the need for improved representation of $\mathrm{BC}$ processing in global models in the Arctic.

With a horizontal resolution of $40 \mathrm{~km}$, a good spatial correlation is found between the horizontal distribution of AOD, the strong divergence regions of the $\mathrm{BC}$ horizontal fluxes in the FT and the spatial distribution of the mean upward BC mass fluxes, underlying ideal conditions for BC poleward transport. This highlights two major biomass burning regions in Siberia, south of Krasnoyarsk region and Yakutia, and one source of anthropogenic pollution in central and northeastern China. Aerosols and $\mathrm{CO}$ emitted from the two boreal forest fire regions are exported towards the Arctic through the north of Yakutia in the region presenting a large horizontal poleward eddy heat flux. Their transport towards the North Pole is caused by low-pressure systems controlling the progression and path of the plumes. In the lowest Arctic atmospheric layers, weak $\mathrm{CO}$ and $\mathrm{BC}$ enhancements are linked to the inefficient transport of European anthropogenic emissions and to a lesser extent to emissions from flaring activities in northern Russia. These emissions are exported over the Barents Sea and transported at low altitudes into the Arctic.

During the cross-polar transport of Siberian and Asian plumes to the Arctic region, a large fraction of $\mathrm{BC}$ particles mixed with sufficient water-soluble compounds become $\mathrm{CCN}$ active and are scavenged by cloud droplets or rain drops via wet deposition associated with the warm section of midlatitude cyclones. The two wet deposition processes, namely the wet removal by large-scale precipitation and the scavenging in wet convective updrafts, contribute almost similarly to the total accumulated deposition of BC. The weak role of dry deposition is limited to the lower troposphere. The simulated transport efficiency of $\mathrm{BC}\left(\mathrm{TE}_{\mathrm{BC}}\right)$, accumulated precipitation along trajectory (APT) and accumulated condensed water along trajectory (ACWT) values provide insights for understanding the wet removal of aerosols transported to the Arctic. The $\mathrm{TE}_{\mathrm{BC}}$ in biomass burning plumes is about $60 \%$ and is found to be due to low APT $(1 \mathrm{~mm})$. In contrast, $\mathrm{TE}_{\mathrm{BC}}$ is small $(<30 \%)$ and APTs are larger $(5-10 \mathrm{~mm})$ in plumes influenced by urban anthropogenic sources or flaring activities in northern Russia and transported at lower altitudes.

The transport efficiency of BC due to large-scale precipitation is responsible for the sharp meridional gradient in the distribution of $\mathrm{BC}$ concentrations. The transport in WCBs, rapidly injecting aerosols into the upper troposphere, removes some but not all carbonaceous aerosols by wet deposition. Cumulus clouds in the mid-latitudes removed more of the low-level aerosol by scavenging or washout than by uplifting it and are responsible for the vertical gradient of $\mathrm{TE}_{\mathrm{BC}}$, especially in the mid-latitudes. Wet deposition in convective updrafts is essentially active below $60^{\circ} \mathrm{N}$, reflecting the distribution of convective precipitation, but is dominated in the Arctic region by the large-scale wet removal associated with the formation of stratocumulus clouds in the PBL producing frequent drizzle. An understanding of the respective contributions of the different wet deposition processes is therefore critically important since it drives the vertical profiles of $\mathrm{BC}$ and tightly modulates the long-range transport of $\mathrm{BC}$ aerosol from Asia and Siberia to the Arctic, with a marked zonal component and transport at higher altitudes.

Code availability. We used WRF-Chem version 3.5.1 modified to include the $\mathrm{KFCuP}$ scheme. After version 3.8, the KFCuP scheme is included in the released code, available at http://www2.mmm.ucar. edu/wrf/users/download/get_source.html.

Data availability. The ACCESS BC and CO data are available by request from the DLR. The PI for the DLR Falcon SP2 data for ACCESS can be reached at bernadett.weinzierl@univie.ac.at. The PI for the CO measurements during ACCESS can be reached at hans.schlager@dlr.de. DARDAR data are publicly available at http: //www.icare.univ-lille1.fr.

Author contributions. The first author performed the WRF-Chem simulations and analyses and drafted the paper; the co-authors contributed text and ideas and discussed the results. Most of the authors participated in the ACCESS campaign in July 2012.

Competing interests. The authors declare that they have no conflict of interest.

Acknowledgements. The research leading to these results received funding from the European Union under grant agreement 265863-ACCESS (http://www.access-eu.org) within the Ocean of Tomorrow call of the European Commission Seventh Framework Programme. The French co-authors acknowledge support from the national Chantier Arctique project, PARCS (Pollution in the Arctic System), funded by CNRS-INSU. We thank the pilots, engineers, and scientists from the DLR flight department for their excellent support during the field campaign. Computer modeling performed 
by Jean-Christophe Raut benefited from access to IDRIS HPC resources (GENCI allocations 2015-017141 and 2016-017141) and the IPSL mesoscale computing center (CICLAD: Calcul Intensif pour le Climat, l'Atmosphère et la Dynamique). We thank the EDGAR team for compiling the HTAPv2 emissions. We acknowledge use of the WRF-Chem preprocessor tool (mozbc, fire_emiss, bio_emiss) provided by the Atmospheric Chemistry Observations and Modeling Lab (ACOM) of NCAR. We acknowledge use of MOZART-4 global model output available at http://www.acom.ucar.edu/wrf-chem/mozart.shtml. Jerome D. Fast, Larry K. Berg and Richard C. Easter were supported by the Office of Science of the US Department of Energy as part of the Atmospheric System Research (ASR) program. The Pacific Northwest National Laboratory (PNNL) is operated by DOE by the Battelle Memorial Institute under contract DE-A06-76RLO976 1830. B. Weinzierl and K. Heimerl were supported by the Helmholtz Association (grant number VH-NG-606) and by the European Research Council under the European Community's Horizon 2020 research and innovation framework program/ERC grant agreement 640458 (A-LIFE). We thank the AERIS-ICARE Data and Services Center for providing access to the DARDAR data used in this study.

Edited by: Federico Fierli

Reviewed by: two anonymous referees

\section{References}

Abel, S. J., Haywood, J. M., Highwood, E. J., Li, J., and Buseck, P. R.: Evolution of biomass burning aerosol properties from an agricultural fire in southern Africa, Geophys. Res. Lett., 30, 1783, https://doi.org/10.1029/2003GL017342, 2003.

Akagi, S. K., Craven, J. S., Taylor, J. W., McMeeking, G. R., Yokelson, R. J., Burling, I. R., Urbanski, S. P., Wold, C. E., Seinfeld, J. H., Coe, H., Alvarado, M. J., and Weise, D. R.: Evolution of trace gases and particles emitted by a chaparral fire in California, Atmos. Chem. Phys., 12, 1397-1421, https://doi.org/10.5194/acp12-1397-2012, 2012.

AMAP: Black Carbon and Ozone as Arctic Climate Forcers, Arctic Monitoring and Assessment Programme (AMAP), Oslo, Norway vii $p, 2015$.

Ancellet, G., Pelon, J., Blanchard, Y., Quennehen, B., Bazureau, A., Law, K. S., and Schwarzenboeck, A.: Transport of aerosol to the Arctic: analysis of CALIOP and French aircraft data during the spring 2008 POLARCAT campaign, Atmos. Chem. Phys., 14, 8235-8254, https://doi.org/10.5194/acp-14-8235-2014, 2014.

Baumgardner, D., Subramanian, R., Twohy, C., Stith, J., and Kok, G.: Scavenging of black carbon by ice crystals over the northern Pacific, Geophys. Res. Lett., 35, L22815, https://doi.org/10.1029/2008GL035764, 2008.

Berg, L. K., Shrivastava, M., Easter, R. C., Fast, J. D., Chapman, E. G., Liu, Y., and Ferrare, R. A.: A new WRF-Chem treatment for studying regional-scale impacts of cloud processes on aerosol and trace gases in parameterized cumuli, Geosci. Model Dev., 8, 409-429, https://doi.org/10.5194/gmd-8-409-2015, 2015.

Berg Jr., L. K., Gustafson Jr., W., Kassianov, E. I., and Deng, L.: Evaluation of a Modified Scheme for Shallow Convection: Implementation of CuP and Case Studies, Mon. Weather Rev., 141, 134-147, https://doi.org/10.1175/MWR-D-12-00136.1, 2013.
Bourgeois, Q. and Bey, I.: Pollution transport efficiency toward the Arctic: Sensitivity to aerosol scavenging and source regions, J. Geophys. Res.-Atmos., 116, D08213, https://doi.org/10.1029/2010JD015096, 2011.

Breider, T. J., Mickley, L. J., Jacob, D. J., Wang, Q., Fisher, J. A., Chang, R., and Alexander, B.: Annual distributions and sources of Arctic aerosol components, aerosol optical depth, and aerosol absorption, J. Geophys. Res.-Atmos., 119, 4107-4124, 2014.

Brioude, J., Arnold, D., Stohl, A., Cassiani, M., Morton, D., Seibert, P., Angevine, W., Evan, S., Dingwell, A., Fast, J. D., Easter, R. C., Pisso, I., Burkhart, J., and Wotawa, G.: The Lagrangian particle dispersion model FLEXPART-WRF version 3.1, Geosci Model Dev., 6, 1889-1904, https://doi.org/10.5194/gmd-6-18892013, 2013.

Brock, C. A., Radke, L. F., Lyons, J. H., and Hobbs, P. V.: Arctic hazes in summer over Greenland and the North American Arctic. I: Incidence and origins, J. Atmos. Chem., 9, 129-148, 1989.

Browse, J., Carslaw, K. S., Arnold, S. R., Pringle, K., and Boucher, O.: The scavenging processes controlling the seasonal cycle in Arctic sulphate and black carbon aerosol, Atmos. Chem. Phys., 12, 6775-6798, https://doi.org/10.5194/acp12-6775-2012, 2012.

Chapman, E. G., Gustafson Jr., W. I., Easter, R. C., Barnard, J. C., Ghan, S. J., Pekour, M. S., and Fast, J. D.: Coupling aerosol-cloud-radiative processes in the WRF-Chem model: Investigating the radiative impact of elevated point sources, Atmos. Chem. Phys., 9, 945-964, https://doi.org/10.5194/acp-9945-2009, 2009.

Corbett, J. J., Lack, D. A., Winebrake, J. J., Harder, S., Silberman, J. A., and Gold, M.: Arctic shipping emissions inventories and future scenarios, Atmos. Chem. Phys., 10, 9689-9704, https://doi.org/10.5194/acp-10-9689-2010, 2010.

Dahlkötter, F., Gysel, M., Sauer, D., Minikin, A., Baumann, R., Seifert, P., Ansmann, A., Fromm, M., Voigt, C., and Weinzierl, B.: The Pagami Creek smoke plume after long-range transport to the upper troposphere over Europe - aerosol properties and black carbon mixing state, Atmos. Chem. Phys., 14, 6111-6137, https://doi.org/10.5194/acp-14-6111-2014, 2014.

Delanoë, J. and Hogan, R. J.: Combined CloudSatCALIPSO-MODIS retrievals of the properties of ice clouds, J. Geophys. Res.-Atmos., 115, D00H29, https://doi.org/10.1029/2009JD012346, 2010.

Di Pierro, M., Jaeglé, L., Eloranta, E. W., and Sharma, S.: Spatial and seasonal distribution of Arctic aerosols observed by the CALIOP satellite instrument (2006-2012), Atmos. Chem. Phys., 13, 7075-7095, https://doi.org/10.5194/acp-137075-2013, 2013.

Easter, R. C., Ghan, S. J., Zhang, Y., Saylor, R. D., Chapman, E. G., Laulainen, N. S., Abdul-Razzak, H., Leung, L. R., Bian, X., and Zaveri, R. A.: MIRAGE: Model description and evaluation of aerosols and trace gases, J. Geophys. Res.-Atmos., 109, D20210, https://doi.org/10.1029/2004JD004571, 2004.

Eckhardt, S., Stohl, A., Wernli, H., James, P., Forster, C., and Spichtinger, N.: A 15-year climatology of warm conveyor belts, J. Climate, 17, 218-237, 2004.

Eckhardt, S., Quennehen, B., Olivié, D. J. L., Berntsen, T. K., Cherian, R., Christensen, J. H., Collins, W., Crepinsek, S., Daskalakis, N., Flanner, M., Herber, A., Heyes, C., Hodnebrog, Ø., Huang, L., Kanakidou, M., Klimont, Z., Langner, J., Law, 
K. S., Lund, M. T., Mahmood, R., Massling, A., Myriokefalitakis, S., Nielsen, I. E., Nøjgaard, J. K., Quaas, J., Quinn, P. K., Raut, J.-C., Rumbold, S. T., Schulz, M., Sharma, S., Skeie, R. B., Skov, H., Uttal, T., von Salzen, K., and Stohl, A.: Current model capabilities for simulating black carbon and sulfate concentrations in the Arctic atmosphere: a multi-model evaluation using a comprehensive measurement data set, Atmos. Chem. Phys., 15, 9413-9433, https://doi.org/10.5194/acp-15-9413-2015, 2015.

Ek, M., Mitchell, K., Lin, Y., Rogers, E., Grunmann, P., Koren, V., Gayno, G., and Tarpley, J.: Implementation of Noah land surface model advances in the National Centers for Environmental Prediction operational mesoscale Eta model, J. Geophys. Res.-Atmos., 108, 8851, https://doi.org/10.1029/2002JD003296, 2003.

Emmons, L. K., Walters, S., Hess, P. G., Lamarque, J.-F., Pfister, G. G., Fillmore, D., Granier, C., Guenther, A., Kinnison, D., Laepple, T., Orlando, J., Tie, X., Tyndall, G., Wiedinmyer, C., Baughcum, S. L., and Kloster, S.: Description and evaluation of the Model for Ozone and Related chemical Tracers, version 4 (MOZART-4), Geosci. Model Dev., 3, 43-67, https://doi.org/10.5194/gmd-3-43-2010, 2010.

Emmons, L. K., Arnold, S. R., Monks, S. A., Huijnen, V., Tilmes, S., Law, K. S., Thomas, J. L., Raut, J.-C., Bouarar, I., Turquety, S., Long, Y., Duncan, B., Steenrod, S., Strode, S., Flemming, J., Mao, J., Langner, J., Thompson, A. M., Tarasick, D., Apel, E. C., Blake, D. R., Cohen, R. C., Dibb, J., Diskin, G. S., Fried, A., Hall, S. R., Huey, L. G., Weinheimer, A. J., Wisthaler, A., Mikoviny, T., Nowak, J., Peischl, J., Roberts, J. M., Ryerson, T., Warneke, C., and Helmig, D.: The POLARCAT Model Intercomparison Project (POLMIP): overview and evaluation with observations, Atmos. Chem. Phys., 15, 6721-6744, https://doi.org/10.5194/acp-15-6721-2015, 2015.

Fast, J. D. and Easter, R. C.: A Lagrangian particle dispersion model compatible with WRF, in: 7th WRF User's Workshop, Boulder, CO, USA, Citeseer, 19-22 June 2006, 2006.

Fast, J. D., Gustafson, W. I., Easter, R. C., Zaveri, R. A., Barnard, J. C., Chapman, E. G., Grell, G. A., and Peckham, S. E.: Evolution of ozone, particulates, and aerosol direct radiative forcing in the vicinity of Houston using a fully coupled meteorology-chemistry-aerosol model, J. Geophys. Res.-Atmos., 111, D21305, https://doi.org/10.1029/2005JD006721, 2006.

Flanner, M. G., Zender, C. S., Randerson, J. T., and Rasch, P. J.: Present-day climate forcing and response from black carbon in snow, J. Geophys. Res.-Atmos., 112, 2007.

Flanner, M. G., Zender, C. S., Hess, P. G., Mahowald, N. M., Painter, T. H., Ramanathan, V., and Rasch, P. J.: Springtime warming and reduced snow cover from carbonaceous particles, Atmos. Chem. Phys., 9, 2481-2497, https://doi.org/10.5194/acp9-2481-2009, 2009.

Franklin, J. E., Drummond, J. R., Griffin, D., Pierce, J. R., Waugh, D. L., Palmer, P. I., Parrington, M., Lee, J. D., Lewis, A. C., Rickard, A. R., Taylor, J. W., Allan, J. D., Coe, H., Walker, K. A., Chisholm, L., Duck, T. J., Hopper, J. T., Blanchard, Y., Gibson, M. D., Curry, K. R., Sakamoto, K. M., Lesins, G., Dan, L., Kliever, J., and Saha, A.: A case study of aerosol scavenging in a biomass burning plume over eastern Canada during the 2011 BORTAS field experiment, Atmos. Chem. Phys., 14, 8449-8460, https://doi.org/10.5194/acp-14-8449-2014, 2014.
Freitas, S. R., Longo, K. M., Chatfield, R., Latham, D., Silva Dias, M. A. F., Andreae, M. O., Prins, E., Santos, J. C., Gielow, R., and Carvalho Jr., J. A.: Including the sub-grid scale plume rise of vegetation fires in low resolution atmospheric transport models, Atmos. Chem. Phys., 7, 3385-3398, https://doi.org/10.5194/acp7-3385-2007, 2007.

Garrett, T. J. and Zhao, C.: Increased Arctic cloud longwave emissivity associated with pollution from mid-latitudes, Nature, 440, 787-789, https://doi.org/10.1038/nature04636, 2006.

Grell, G., Freitas, S. R., Stuefer, M., and Fast, J.: Inclusion of biomass burning in WRF-Chem: impact of wildfires on weather forecasts, Atmos. Chem. Phys., 11, 5289-5303, https://doi.org/10.5194/acp-11-5289-2011, 2011.

Grell, G. A., Peckham, S. E., Schmitz, R., McKeen, S. A., Frost, G., Skamarock, W. C., and Eder, B.: Fully coupled "online" chemistry within the WRF model, Atmos. Environ., 39, 6957-6975, 2005.

Guenther, A., Karl, T., Harley, P., Wiedinmyer, C., Palmer, P. I., and Geron, C.: Estimates of global terrestrial isoprene emissions using MEGAN (Model of Emissions of Gases and Aerosols from Nature), Atmos. Chem. Phys., 6, 3181-3210, https://doi.org/10.5194/acp-6-3181-2006, 2006.

Gustafson, W. I., Chapman, E. G., Ghan, S. J., Easter, R. C., and Fast, J. D.: Impact on modeled cloud characteristics due to simplified treatment of uniform cloud condensation nuclei during NEAQS 2004, Geophys. Res. Lett., 34, L19809, https://doi.org/10.1029/2007GL030021, 2007.

Hansen, J. and Nazarenko, L.: Soot climate forcing via snow and ice albedos, P. Natl. Acad. Sci. USA, 101, 423-428, 2004.

Hubanks, P. A., King, M. D., Platnick, S., and Pincus, R.: MODIS atmosphere $\mathrm{L} 3$ gridded product algorithm theoretical basis document, ATBD Reference Number: ATBD-MOD-30, 30, 96 pp., 2008.

Huffman, G. J., Adler, R. F., Morrissey, M. M., Bolvin, D. T., Curtis, S., Joyce, R., McGavock, B., and Susskind, J.: Global precipitation at one-degree daily resolution from multisatellite observations, J. Hydrometeorol., 2, 36-50, 2001.

Iacono, M. J., Delamere, J. S., Mlawer, E. J., Shephard, M. W., Clough, S. A., and Collins, W. D.: Radiative forcing by longlived greenhouse gases: Calculations with the AER radiative transfer models, J. Geophys. Res.-Atmos., 113, D13103, https://doi.org/10.1029/2008JD009944, 2008.

IPCC: Climate Change 2013: The Physical Science Basis. Contribution of Working Group I to the Fifth Assessment Report of the Intergovernmental Panel on Climate Change, Cambridge University Press, Cambridge, UK and New York, NY, USA, https://doi.org/10.1017/CBO9781107415324, 2013.

Jacobson, M. Z.: Climate response of fossil fuel and biofuel soot, accounting for soot's feedback to snow and sea ice albedo and emissivity, J. Geophys. Res.-Atmos., 109, D21201, https://doi.org/10.1029/2004JD004945, 2004.

Jacobson, M. Z.: Short-term effects of controlling fossil-fuel soot, biofuel soot and gases, and methane on climate, Arctic ice, and air pollution health, J. Geophys. Res.-Atmos., 115, D14209, https://doi.org/10.1029/2009JD013795, 2010.

Janjic, Z. I.: The step-mountain eta coordinate model: Further developments of the convection, viscous sublayer, and turbulence closure schemes, Mon. Weather Rev., 122, 927-945, 1994. 
Kain, J. S.: The Kain-Fritsch Convective Parameterization: An Update, J. Appl. Meteorol., 43, 170-181, https://doi.org/10.1175/15200450(2004)043<0170:TKCPAU>2.0.CO;2, 2004.

Koch, D. and Hansen, J.: Distant origins of Arctic black carbon: a Goddard Institute for Space Studies ModelE experiment, J. Geophys. Res.-Atmos., 110, D04204, https://doi.org/10.1029/2004JD005296, 2005.

Koch, D., Schulz, M., Kinne, S., McNaughton, C., Spackman, J. R., Balkanski, Y., Bauer, S., Berntsen, T., Bond, T. C., Boucher, O., Chin, M., Clarke, A., De Luca, N., Dentener, F., Diehl, T., Dubovik, O., Easter, R., Fahey, D. W., Feichter, J., Fillmore, D., Freitag, S., Ghan, S., Ginoux, P., Gong, S., Horowitz, L., Iversen, T., Kirkevåg, A., Klimont, Z., Kondo, Y., Krol, M., Liu, X., Miller, R., Montanaro, V., Moteki, N., Myhre, G., Penner, J. E., Perlwitz, J., Pitari, G., Reddy, S., Sahu, L., Sakamoto, H., Schuster, G., Schwarz, J. P., Seland, Ø., Stier, P., Takegawa, N., Takemura, T., Textor, C., van Aardenne, J. A., and Zhao, Y.: Evaluation of black carbon estimations in global aerosol models, Atmos. Chem. Phys., 9, 9001-9026, https://doi.org/10.5194/acp-99001-2009, 2009.

Koike, M., Kondo, Y., Kita, K., Takegawa, N., Masui, Y., Miyazaki, Y., Ko, M., Weinheimer, A., Flocke, F., Weber, R., Thornton, D. C., Sachse, G. W., Vay, S. A., Blake, D. R., Streets, D. G., Eisele, F. L., Sandholm, S. T., Singh, H. B., and Talbot, R. W.: Export of anthropogenic reactive nitrogen and sulfur compounds from the East Asia region in spring, J. Geophys. Res.-Atmos., 108, 8789, https://doi.org/10.1029/2002JD003284, 2003.

Kondo, Y., Matsui, H., Moteki, N., Sahu, L., Takegawa, N., Kajino, M., Zhao, Y., Cubison, M., Jimenez, J., Vay, S., Diskin, G. S., Anderson, B., Wisthaler, A., Mikoviny, T., Fuelberg, H. E., Blake, D. R., Huey, G., Weinheimer, A. J., Knapp, D. J., and Brune, W. H.: Emissions of black carbon, organic, and inorganic aerosols from biomass burning in North America and Asia in 2008, J. Geophys. Res.-Atmos., 116, D08204, https://doi.org/10.1029/2010JD015152, 2011.

Laborde, M., Schnaiter, M., Linke, C., Saathoff, H., Naumann, K.H., Möhler, O., Berlenz, S., Wagner, U., Taylor, J. W., Liu, D., Flynn, M., Allan, J. D., Coe, H., Heimerl, K., Dahlkötter, F., Weinzierl, B., Wollny, A. G., Zanatta, M., Cozic, J., Laj, P., Hitzenberger, R., Schwarz, J. P., and Gysel, M.: Single Particle Soot Photometer intercomparison at the AIDA chamber, Atmos. Meas. Tech., 5, 3077-3097, https://doi.org/10.5194/amt-5-30772012, 2012.

Lavoué, D., Liousse, C., Cachier, H., Stocks, B. J., and Goldammer, J. G.: Modeling of carbonaceous particles emitted by boreal and temperate wildfires at northern latitudes, J. Geophys. Res.Atmos., 105, 26871-26890, 2000.

Law, K. S. and Stohl, A.: Arctic Air Pollution: Origins and Impacts, Science, 315, 1537-1540, https://doi.org/10.1126/science.1137695, 2007.

Law, K. S., Stohl, A., Quinn, P. K., Brock, C. A., Burkhart, J. F., Paris, J.-D., Ancellet, G., Singh, H. B., Roiger, A., Schlager, H., Dibb, J., Jacob, D. J., Arnold, S. R., Pelon, J., and Thomas, J. L.: Arctic air pollution: new insights from POLARCAT-IPY, B. Am. Meteorol. Soc., 95, 1873-1895, 2014.

Lee, Y. H., Lamarque, J.-F., Flanner, M. G., Jiao, C., Shindell, D. T., Berntsen, T., Bisiaux, M. M., Cao, J., Collins, W. J., Curran, M., Edwards, R., Faluvegi, G., Ghan, S., Horowitz,
L. W., McConnell, J. R., Ming, J., Myhre, G., Nagashima, T., Naik, V., Rumbold, S. T., Skeie, R. B., Sudo, K., Takemura, T., Thevenon, F., Xu, B., and Yoon, J.-H.: Evaluation of preindustrial to present-day black carbon and its albedo forcing from Atmospheric Chemistry and Climate Model Intercomparison Project (ACCMIP), Atmos. Chem. Phys., 13, 2607-2634, https://doi.org/10.5194/acp-13-2607-2013, 2013.

Lindsay, R. W., Zhang, J., Schweiger, A., Steele, M., and Stern, H.: Arctic Sea Ice Retreat in 2007 Follows Thinning Trend, J. Climate, 22, 165-176, https://doi.org/10.1175/2008JCLI2521.1, 2009.

Lubin, D. and Vogelmann, A. M.: A climatologically significant aerosol longwave indirect effect in the Arctic, Nature, 439, 453456, 2006.

Ma, P.-L., Rasch, P. J., Wang, H., Zhang, K., Easter, R. C., Tilmes, S., Fast, J. D., Liu, X., Yoon, J.-H., and Lamarque, J.-F.: The role of circulation features on black carbon transport into the Arctic in the Community Atmosphere Model version 5 (CAM5), J. Geophys. Res.-Atmos., 118, 4657-4669, https://doi.org/10.1002/jgrd.50411, 2013.

Ma, P.-L., Rasch, P. J., Fast, J. D., Easter, R. C., Gustafson Jr., W. I., Liu, X., Ghan, S. J., and Singh, B.: Assessing the CAM5 physics suite in the WRF-Chem model: implementation, resolution sensitivity, and a first evaluation for a regional case study, Geosci. Model Dev., 7, 755-778, https://doi.org/10.5194/gmd-7755-2014, 2014.

Madonna, E., Wernli, H., Joos, H., and Martius, O.: Warm Conveyor Belts in the ERA-Interim Dataset (1979-2010). Part I: Climatology and Potential Vorticity Evolution, J. Climate, 27, 3-26, https://doi.org/10.1175/JCLI-D-12-00720.1, 2014.

Manabe, S., Spelman, M., and Stouffer, R.: Transient responses of a coupled ocean-atmosphere model to gradual changes of atmospheric $\mathrm{CO}_{2}$. Part II: Seasonal response, J. Climate, 5, 105-126, 1992.

Marelle, L., Thomas, J. L., Raut, J.-C., Law, K. S., Jalkanen, J.P., Johansson, L., Roiger, A., Schlager, H., Kim, J., Reiter, A., and Weinzierl, B.: Air quality and radiative impacts of Arctic shipping emissions in the summertime in northern Norway: from the local to the regional scale, Atmos. Chem. Phys., 16, 2359 2379, https://doi.org/10.5194/acp-16-2359-2016, 2016.

Matsui, H., Kondo, Y., Moteki, N., Takegawa, N., Sahu, L., Zhao, Y., Fuelberg, H., Sessions, W., Diskin, G., Blake, D., Wisthaler, A., and Koike, M.: Seasonal variation of the transport of black carbon aerosol from the Asian continent to the Arctic during the ARCTAS aircraft campaign, J. Geophys. Res.-Atmos., 116, D05202, https://doi.org/10.1029/2010JD015067, 2011.

Monks, S. A., Arnold, S. R., Emmons, L. K., Law, K. S., Turquety, S., Duncan, B. N., Flemming, J., Huijnen, V., Tilmes, S., Langner, J., Mao, J., Long, Y., Thomas, J. L., Steenrod, S. D., Raut, J. C., Wilson, C., Chipperfield, M. P., Diskin, G. S., Weinheimer, A., Schlager, H., and Ancellet, G.: Multi-model study of chemical and physical controls on transport of anthropogenic and biomass burning pollution to the Arctic, Atmos. Chem. Phys., 15, 3575-3603, https://doi.org/10.5194/acp-15-3575-2015, 2015.

Morrison, H., Thompson, G., and Tatarskii, V.: Impact of cloud microphysics on the development of trailing stratiform precipitation in a simulated squall line: Comparison of one-and two-moment schemes, Mon. Weather Rev., 137, 991-1007, 2009. 
Moteki, N., Kondo, Y., and Nakamura, S.-I.: Method to measure refractive indices of small nonspherical particles: Application to black carbon particles, J. Aerosol Sci., 41, 513-521, 2010.

Murrells, T., Passant, N., Thistlethwaite, G., Wagner, A., Li, Y., Bush, T., Norris, J., Walker, C., Stewart, R., Tsagatakis, I., Whiting, R., Conolly, C., Okamura, S., Peirce, M., Sneddon, S., Webb, J., Thomas, J., MacCarthy, J., Choudrie, S., and Brophy, N.: UK emissions of air pollutants 1970 to 2008, AEA Energy and Environment, 2010.

Orsolini, Y. J. and Sorteberg, A.: Projected changes in Eurasian and Arctic summer cyclones under global warming in the Bergen Climate Model, Atmos. Oceanic Sci. Lett., 2, 62-67, 2009.

Oshima, N., Kondo, Y., Moteki, N., Takegawa, N., Koike, M., Kita, K., Matsui, H., Kajino, M., Nakamura, H., Jung, J., and Kim, Y. J.: Wet removal of black carbon in Asian outflow: Aerosol Radiative Forcing in East Asia (A-FORCE) aircraft campaign, J. Geophys. Res.-Atmos., 117, D03204, https://doi.org/10.1029/2011JD016552, 2012.

Oshima, N., Koike, M., Kondo, Y., Nakamura, H., Moteki, N., Matsui, H., Takegawa, N., and Kita, K.: Vertical transport mechanisms of black carbon over East Asia in spring during the A-FORCE aircraft campaign, J. Geophys. Res.-Atmos., 118, 13175-13198, https://doi.org/10.1002/2013JD020262, 2013.

Paris, J.-D., Stohl, A., Nédélec, P., Arshinov, M. Yu., Panchenko, M. V., Shmargunov, V. P., Law, K. S., Belan, B. D., and Ciais, P.: Wildfire smoke in the Siberian Arctic in summer: source characterization and plume evolution from airborne measurements, Atmos. Chem. Phys., 9, 9315-9327, https://doi.org/10.5194/acp9-9315-2009, 2009.

Petters, M. D., Carrico, C. M., Kreidenweis, S. M., Prenni, A. J., DeMott, P. J., Collett, J. L., and Moosmüller, H.: Cloud condensation nucleation activity of biomass burning aerosol, J. Geophys. Res.-Atmos., 114, D22205, https://doi.org/10.1029/2009JD012353, 2009.

Ponomarev, E. I.: Radiative power of wildfires in Siberia on the basis of TERRA/Modis imagery processing, Folia Forestalia Polonica, Seria A-Forestry, 55, 102-110, 2013.

Quinn, P. K., Bates, T. S., Baum, E., Doubleday, N., Fiore, A. M., Flanner, M., Fridlind, A., Garrett, T. J., Koch, D., Menon, S., Shindell, D., Stohl, A., and Warren, S. G.: Shortlived pollutants in the Arctic: their climate impact and possible mitigation strategies, Atmos. Chem. Phys., 8, 1723-1735, https://doi.org/10.5194/acp-8-1723-2008, 2008.

Rastigejev, Y., Park, R., Brenner, M. P., and Jacob, D. J.: Resolving intercontinental pollution plumes in global models of atmospheric transport, J. Geophys. Res.-Atmos., 115, D02302, https://doi.org/10.1029/2009JD012568, 2010.

Roiger, A., Schlager, H., Schäfler, A., Huntrieser, H., Scheibe, M., Aufmhoff, H., Cooper, O. R., Sodemann, H., Stohl, A., Burkhart, J., Lazzara, M., Schiller, C., Law, K. S., and Arnold, F.: Insitu observation of Asian pollution transported into the Arctic lowermost stratosphere, Atmos. Chem. Phys., 11, 10975-10994, https://doi.org/10.5194/acp-11-10975-2011, 2011.

Roiger, A., Thomas, J.-L., Schlager, H., Law, K. S., Kim, J., Schäfler, A., Weinzierl, B., Dahlkötter, F., Krisch, I., and Marelle, L.: Quantifying emerging local anthropogenic emissions in the Arctic region: The ACCESS aircraft campaign experiment, B. Am. Meteorol. Soc., 96, 441-460, 2015.
Sahu, L., Kondo, Y., Moteki, N., Takegawa, N., Zhao, Y., Cubison, M., Jimenez, J., Vay, S., Diskin, G., Wisthaler, A., Mikoviny, T., Huey, L. G., Weinheimer, A. J., and Knapp, D. J.: Emission characteristics of black carbon in anthropogenic and biomass burning plumes over California during ARCTAS-CARB 2008, J. Geophys. Res.-Atmos., 117, 21562202, https://doi.org/10.1029/2011JD017401, 2012.

Schmale, J., Schneider, J., Ancellet, G., Quennehen, B., Stohl, A., Sodemann, H., Burkhart, J. F., Hamburger, T., Arnold, S. R., Schwarzenboeck, A., Borrmann, S., and Law, K. S.: Source identification and airborne chemical characterisation of aerosol pollution from long-range transport over Greenland during POLARCAT summer campaign 2008, Atmos. Chem. Phys., 11, 1009710123, https://doi.org/10.5194/acp-11-10097-2011, 2011.

Schwarz, J., Gao, R., Fahey, D., Thomson, D., Watts, L., Wilson, J., Reeves, J., Darbeheshti, M., Baumgardner, D., Kok, G., Chung, S. H., Schulz, M., Hendricks, J. Lauer, A., Kärcher, B., Slowik, J. G., Rosenlof, K. H., Thompson, T. L., Langford, A. O., Loewenstein, M., and Aikin, K. C.: Single-particle measurements of midlatitude black carbon and light-scattering aerosols from the boundary layer to the lower stratosphere, J. Geophys. Res.Atmos., 111, D16207, https://doi.org/10.1029/2006JD007076, 2006.

Schwarz, J., Samset, B., Perring, A., Spackman, J., Gao, R., Stier, P., Schulz, M., Moore, F., Ray, E. A., and Fahey, D.: Globalscale seasonally resolved black carbon vertical profiles over the Pacific, Geophys. Res. Lett., 40, 5542-5547, 2013.

Schwarz, J. P., Weinzierl, B., Samset, B. H., Dollner, M., Heimerl, K., Markovic, M. Z., Perring, A. E., and Ziemba, L.: Aircraft measurements of black carbon vertical profiles show upper tropospheric variability and stability, Geophys. Res. Lett., 44, 11321140, https://doi.org/10.1002/2016GL071241, 2017.

Seinfeld, J. H. and Pandis, S. N.: Atmospheric chemistry and physics, vol. 450, Wiley, Hoboken, USA, 2006.

Serreze, M. C. and Barrett, A. P.: The summer cyclone maximum over the central Arctic Ocean, J. Climate, 21, 1048-1065, 2008.

Sessions, W. R., Fuelberg, H. E., Kahn, R. A., and Winker, D. M.: An investigation of methods for injecting emissions from boreal wildfires using WRF-Chem during ARCTAS, Atmos. Chem. Phys., 11, 5719-5744, https://doi.org/10.5194/acp-115719-2011, 2011.

Sharma, S., Ishizawa, M., Chan, D., Lavoué, D., Andrews, E., Eleftheriadis, K., and Maksyutov, S.: 16-year simulation of Arctic black carbon: Transport, source contribution, and sensitivity analysis on deposition, J. Geophys. Res.-Atmos., 118, 943-964, 2013.

Shaw, W. J., Allwine, K. J., Fritz, B. G., Rutz, F. C., Rishel, J. P., and Chapman, E. G.: An evaluation of the wind erosion module in DUSTRAN, Atmos. Environ., 42, 1907-1921, 2008.

Shindell, D. and Faluvegi, G.: Climate response to regional radiative forcing during the twentieth century, Nat. Geosci., 2, 294-300, https://doi.org/10.1038/ngeo473, 2009.

Shindell, D. T., Chin, M., Dentener, F., Doherty, R. M., Faluvegi, G., Fiore, A. M., Hess, P., Koch, D. M., MacKenzie, I. A., Sanderson, M. G., Schultz, M. G., Schulz, M., Stevenson, D. S., Teich, H., Textor, C., Wild, O., Bergmann, D. J., Bey, I., Bian, H., Cuvelier, C., Duncan, B. N., Folberth, G., Horowitz, L. W., Jonson, J., Kaminski, J. W., Marmer, E., Park, R., Pringle, K. J., Schroeder, S., Szopa, S., Takemura, T., Zeng, G., Keat- 
ing, T. J., and Zuber, A.: A multi-model assessment of pollution transport to the Arctic, Atmos. Chem. Phys., 8, 5353-5372, https://doi.org/10.5194/acp-8-5353-2008, 2008.

Skamarock, W. C. and Klemp, J. B.: A time-split nonhydrostatic atmospheric model for weather research and forecasting applications, J. Comput. Phys., 227, 3465-3485, 2008.

Sodemann, H., Pommier, M., Arnold, S. R., Monks, S. A., Stebel, K., Burkhart, J. F., Hair, J. W., Diskin, G. S., Clerbaux, C., Coheur, P.-F., Hurtmans, D., Schlager, H., Blechschmidt, A.M., Kristjánsson, J. E., and Stohl, A.: Episodes of crosspolar transport in the Arctic troposphere during July 2008 as seen from models, satellite, and aircraft observations, Atmos. Chem. Phys., 11, 3631-3651, https://doi.org/10.5194/acp-113631-2011, 2011.

Stauffer, D. R. and Seaman, N. L.: Use of four-dimensional data assimilation in a limited-area mesoscale model. Part I: Experiments with synoptic-scale data, Mon. Weather Rev., 118, 1250-1277, 1990.

Stith, J. L., Twohy, C. H., DeMott, P. J., Baumgardner, D., Campos, T., Gao, R., and Anderson, J.: Observations of ice nuclei and heterogeneous freezing in a Western Pacific extratropical storm, Atmos. Chem. Phys., 11, 6229-6243, https://doi.org/10.5194/acp11-6229-2011, 2011.

Stohl, A.: Characteristics of atmospheric transport into the Arctic troposphere, J. Geophys. Res.-Atmos., 111, D11306, https://doi.org/10.1029/2005JD006888, 2006.

Stohl, A., Forster, C., Frank, A., Seibert, P., and Wotawa, G.: Technical note: The Lagrangian particle dispersion model FLEXPART version 6.2, Atmos. Chem. Phys., 5, 2461-2474, https://doi.org/10.5194/acp-5-2461-2005, 2005.

Stohl, A., Klimont, Z., Eckhardt, S., Kupiainen, K., Shevchenko, V. P., Kopeikin, V. M., and Novigatsky, A. N.: Black carbon in the Arctic: the underestimated role of gas flaring and residential combustion emissions, Atmos. Chem. Phys., 13, 8833-8855, https://doi.org/10.5194/acp-13-8833-2013, 2013.

Stohl, A., Aamaas, B., Amann, M., Baker, L. H., Bellouin, N., Berntsen, T. K., Boucher, O., Cherian, R., Collins, W., Daskalakis, N., Dusinska, M., Eckhardt, S., Fuglestvedt, J. S., Harju, M., Heyes, C., Hodnebrog, Ø., Hao, J., Im, U., Kanakidou, M., Klimont, Z., Kupiainen, K., Law, K. S., Lund, M. T., Maas, R., MacIntosh, C. R., Myhre, G., Myriokefalitakis, S., Olivié, D., Quaas, J., Quennehen, B., Raut, J.-C., Rumbold, S. T., Samset, B. H., Schulz, M., Seland, Ø., Shine, K. P., Skeie, R. B., Wang, S., Yttri, K. E., and Zhu, T.: Evaluating the climate and air quality impacts of short-lived pollutants, Atmos. Chem. Phys., 15, 10529-10566, https://doi.org/10.5194/acp-15-105292015, 2015.

Taylor, J. W., Allan, J. D., Allen, G., Coe, H., Williams, P. I., Flynn, M. J., Le Breton, M., Muller, J. B. A., Percival, C. J., Oram, D., Forster, G., Lee, J. D., Rickard, A. R., Parrington, M., and Palmer, P. I.: Size-dependent wet removal of black carbon in Canadian biomass burning plumes, Atmos. Chem. Phys., 14, 13755-13771, https://doi.org/10.5194/acp-14-137552014, 2014.

Tomasi, C., Vitale, V., Lupi, A., Di Carmine, C., Campanelli, M., Herber, A., Treffeisen, R., Stone, R. S., Andrews, E., Sharma, S., Radionov, V., von Hoyningen-Huene, W., Stebel, K., Hansen, G. H., Myhre, C. L., Wehrli, C., Aaltonen, V., Lihavainen, H., Virkkula, A., Hillamo, R., Ström, J., Toledano, C., Ca- chorro, V. E., Ortiz, P., de Frutos, A. M., Blindheim, S., Frioud, M., Gausa, M., Zielinski, T., Petelski, T., and Yamanouchi, T.: Aerosols in polar regions: A historical overview based on optical depth and in situ observations, J. Geophys. Res.-Atmos., 112, D16205, https://doi.org/10.1029/2007JD008432, 2007.

Twohy, C. H., DeMott, P. J., Pratt, K. A., Subramanian, R., Kok, G. L., Murphy, S. M., Lersch, T., Heymsfield, A. J., Wang, Z., Prather, K. A., and Seinfeld, J. H.: Relationships of biomassburning aerosols to ice in orographic wave clouds, J. Atmos. Sci., 67, 2437-2450, 2010.

van der Gon, H. D., Hendriks, C., Kuenen, J., Segers, A., and Visschedijk, A.: Description of Current Temporal Emission Patterns and Sensitivity of Predicted AQ for Temporal Emission Patterns, EU FP7 MACC deliverable report, 2011.

Vignati, E., Karl, M., Krol, M., Wilson, J., Stier, P., and Cavalli, F.: Sources of uncertainties in modelling black carbon at the global scale, Atmos. Chem. Phys., 10, 2595-2611, https://doi.org/10.5194/acp-10-2595-2010, 2010.

Wang, H., Rasch, P. J., Easter, R. C., Singh, B., Zhang, R., Ma, P.-L., Qian, Y., Ghan, S. J., and Beagley, N.: Using an explicit emission tagging method in global modeling of source-receptor relationships for black carbon in the Arctic: Variations, sources, and transport pathways, J. Geophys. Res.-Atmos., 119, 1288812909, https://doi.org/10.1002/2014JD022297, 2014.

Warneke, C., Froyd, K., Brioude, J., Bahreini, R., Brock, C., Cozic, J., De Gouw, J., Fahey, D., Ferrare, R., Holloway, J., Middlebrook, A. M., Miller, L., Montzka, S., Schwarz, J. P., Sodemann, H., Spackman, J. R., and Stohl, A.: An important contribution to springtime Arctic aerosol from biomass burning in Russia, Geophys. Res. Lett., 37, L01801, https://doi.org/10.1029/2009GL041816, 2010.

Warren, S. G. and Wiscombe, W. J.: A model for the spectral albedo of snow. II: Snow containing atmospheric aerosols, J. Atmos. Sci., 37, 2734-2745, 1980.

Wesely, M. and Hicks, B.: A review of the current status of knowledge on dry deposition, Atmos. Environ., 34, 2261-2282, 2000.

Wiedinmyer, C., Akagi, S. K., Yokelson, R. J., Emmons, L. K., AlSaadi, J. A., Orlando, J. J., and Soja, A. J.: The Fire INventory from NCAR (FINN): a high resolution global model to estimate the emissions from open burning, Geosci. Model Dev., 4, 625641, https://doi.org/10.5194/gmd-4-625-2011, 2011.

Wild, O., Zhu, X., and Prather, M. J.: Fast-J: Accurate simulation of in-and below-cloud photolysis in tropospheric chemical models, J. Atmos. Chem., 37, 245-282, 2000.

Zaveri, R. A. and Peters, L. K.: A new lumped structure photochemical mechanism for large-scale applications, J. Geophys. Res.Atmos., 104, 30387-30415, 1999.

Zaveri, R. A., Easter, R. C., Fast, J. D., and Peters, L. K.: Model for simulating aerosol interactions and chemistry (MOSAIC), J. Geophys. Res.-Atmos., 113, L01801, https://doi.org/10.1029/2009GL041816, 2008.

Zhao, C. and Garrett, T. J.: Effects of Arctic haze on surface cloud radiative forcing, Geophys. Res. Lett., 42, 557-564, 2015. 